\title{
Maximizing Yields, Nutrient Uptake and Balance for Mustard-Mungbean-T. Aman Rice Cropping Systems through Nutrient Management Practices in Calcareous Soils
}

\author{
M. A. Quddus ${ }^{1}$, M. J. Abedin Mian², H. M. Naser ${ }^{1}$, M. A. Hossain ${ }^{1} \&$ S. Sultana ${ }^{1}$ \\ ${ }^{1}$ Bangladesh Agricultural Research Institute, Joydebpur, Gazipur Sadar, Gazipur, Bangladesh \\ ${ }^{2}$ Department of Soil Science, Bangladesh Agricultural University, Mymensingh, Bangladesh \\ Correspondence: M. A. Quddus, Bangladesh Agricultural Research Institute, Joydebpur, Gazipur Sadar, Gazipur \\ 1701, Bangladesh. E-mail: quddus06@yahoo.com
}

Received: June 13, 2017

doi:10.5539/jas.v9n9p210
Accepted: July 18, $2017 \quad$ Online Published: August 15, 2017

URL: https://doi.org/10.5539/jas.v9n9p210

\begin{abstract}
The experiment was conducted to measure crop yields, nutrient concentration, nutrient uptake and balance by using different nutrient management practices for mustard-mungbean- $T$. aman rice cropping system in calcareous soil of Madaripur, Bangladesh. Different nutrient management practices were absolute nutrient control $\left(T_{1}\right)$; farmer's practice $\left(T_{2}\right)$; AEZ based nutrient application $\left(T_{3}\right)$ and soil test based nutrient application $\left(\mathrm{T}_{4}\right)$. The practices were compared in a randomized completely block design with three replications over two consecutive years. The average yield through application of soil test based nutrient $\left(\mathrm{T}_{4}\right)$ was showed effective to get highest yields of mustard $\left(1530 \mathrm{~kg} \mathrm{ha}^{-1}\right)$, mungbean $\left(1632 \mathrm{~kg} \mathrm{ha}^{-1}\right)$ and $\mathrm{T}$. aman rice $\left(4729 \mathrm{~kg} \mathrm{ha}^{-1}\right)$. The same practices $\left(\mathrm{T}_{4}\right)$ exhibited the greatest nutrients uptake by the test crops. The apparent balance of $\mathrm{N}$ and $\mathrm{K}$ was negative; however it was less negative and less deficiency detect in $\mathrm{T}_{4}$ treatment. Positive balance of $\mathrm{P}$ observed in all practices except in $T_{1}$. There was a positive $S$ balance $\left(7.60 \mathrm{~kg} \mathrm{ha}^{-1}\right)$ in $T_{4}$ but negative in $T_{1}, T_{2}$ and $T_{3}$. Zinc balance was found positive in $T_{3}$ and $T_{4}$ and negative in $T_{1}$ and $T_{2}$. Boron balance in the system was neutral or slightly positive in $T_{1}$ and negative in $T_{2}$ but positive in $T_{3}$ and $T_{4}$. Organic matter, N, P, S, Zn and B status in soil was improved by $\mathrm{T}_{4}$ treatment. The results suggested that the soil test based nutrient application is viable and sustainable for mustard-mungbean-T. aman rice cropping system in calcareous soils of Bangladesh.
\end{abstract}

Keywords: crops yield, nutrient uptake and balance, mustard-mungbean-T. aman rice, cacareous soil

\section{Introduction}

Bangladesh is a heavy populated (population density about 1008 per sq. km.) country globally that an increasing rate $1.19 \%$ per year. Raising populations have need construction of houses, roads and industrial infrastructure resulted agricultural land loss about $0.73 \%$ per annum (BBS, 2012). On the other hand, farmers of Bangladesh are practicing different cropping system depending on soil type, crop suitability, economic benefit and climatic conditions (Vaidyanathan, 1987). The patterns are mainly rice based, although wheat is grown in some areas (Sheikh et al., 2009; Islam et al., 2007). Rice crop and rice based cropping system (rice-rice or rice-wheat) are dominated in South East Asia (Prasad et al., 2002). Calcareous soils of Bangladesh under the agro-ecological zone-Low Ganges River Floodplain. Oilseed and pulse are the important group of crops in calcareous soils which are mostly grown in rabi (winter) and kharif-I (summer) season but area of those crops decreased due to increasing cultivation of irrigated boro (long durated) rice (FRG, 2012). Recently, developments of short duration varities of mustard, mungbean and rice have been created opportunity to accommodate three or more crops in same piece of land in a year (Mondal et al., 2015). Mustard (Brassica napus), mungbean (Vigna radiata) and T. aman rice (Oryza sativa L.) grown sequentially in an annual rotation constitute a mustard-mungbean-T. aman cropping system (Iqbal et al., 1990). Production of mustard, mungbean and T. aman rice has primitive domestic demand in Bangladesh. Presently, those are the preferred crops for human consumption and nutrition (Sheikh et al., 2009). Legume crop in between oilseed and cereal may contribute to maintain soil fertility (Ali et al., 1997).

Furthermore, intensive rice-based cropping system including rice-wheat (RW) or rice-rice causes astonishing depletion of soil nutrients and hazard to crop productivity (Chitdeshwari et al., 2011; Islam, 1995; Prasad et al., 
1999). Growing populations have needed high yielding varieties of crop and to be inceased cropping intensity vertically (three or four crops in a same piece of land in a year) for mitigate the food demand. As a result, need higher amount of nutrients from soils resulting in depletion of soil organic matter and deterioration of soil fertility, poses a warning to sustainable crop production (Hasan et al., 2003; Islam et al., 2002). Farmers normally use lower or higher dose of fertilizers on single crop basis, not the cropping system, which created imbalances in soil nutrients (Kabir et al., 2002). Moreover, continuous cropping without adequate replacement of removed nutrients and nutrient loss through erosion, leaching, and gaseous emission have caused depletion soil fertility as well as soil organic matter (Yu et al., 2014; Tirol-Padre et al., 2007). Besides, low levels (deficiency) of plant nutrients (macro and micro) in calcareous soil of Bangladesh accompanied with improper nutrient management are constraints for food security and malnutrition. The success nutrient management practice depends on how accurately the knowledge of fertility status of soil and the requirement for addition of nutrients to soil for the crops productivity (Biswas et al., 2003).

Plant nutrition research can be helped to eliminate the constraints and sustaining food security (Hossain, 2007). Sepecific plant parts analysis denotes the nutrient concentrations in plant (Jacobsen \& Jasper, 1991). Nutrient concentrations in plant samples are below or above over nutrient critical limit an indicated in plant is deficiency or sufficiency range of that definite element (Havlin et al., 1999). Plant analysis process improves the correct diagnosis and can be identifyed hidden hunger or pseudo deficiencies of nutrient (Havlin et al., 1999).

From now, it is important to develop a cropping system based fertilizer dose for specific agro-ecological zone. Quantification of the loss or add of nutrients under different cropping system has been less attended in calcareous soils of Bangladesh. Nutrient balance is an important tool for assessing the fate of removal, reserve and added nutrients in soils (Blaise et al., 2005; Phong et al., 2011). Nutrient balance has been helped of plant fertilization and yield maximization (Paul Fixen et al., 2014; Bindraban et al., 2000; Smaling et al., 1993).

Different studied reported on balanced fertilization for single crop or cropping system productivity.The highest grain and stover yield of maize (7.71 and $14.05 \mathrm{tha}^{-1}$ ) received from the treatment 250-76-88-7.4 kg N-P-K-Zn $\mathrm{ha}^{-1}$, respectively (Paramasivan et al., 2012). Positive yield change in cropping system were observed in balanced applications of NPK and combined application of fertilizer (NPK) with pig manure (NK + PM) or rice straw (NP + RS and NPK + RS) (Yulin Liao et al., 2010). Balance fertilization with manure gave highest mustard yield $2200 \mathrm{~kg} \mathrm{ha}^{-1}$ (Rundala et al., 2013). Recommended inorganic fertilizer dose along with biofertilizer contributed to get bitter mungbean yield that was three fold over control treatment (Singh et al., 2014; Lal Bahadur \& Tiwari, 2014). Soil test based fertilizer application exhibited positive yield increase in chickpea-mungbean-T. aman rice cropping system where the highest yields were chickpea $\left(1524 \mathrm{~kg} \mathrm{ha}^{-1}\right)$, mungbean $\left(2208 \mathrm{~kg} \mathrm{ha}^{-1}\right)$ and $\mathrm{T}$. aman rice (5414 $\left.\mathrm{kg} \mathrm{ha}^{-1}\right)$ (Quddus et al., 2012).

This is hypothised that the current fertilizer recommendation could be improved for a definite cropping system. Thus, the aim of this study was to compare the different nutrient management practices on nutrient concentration, nutrient uptake and balance for the mustard-mungbean-T. aman rice cropping system and to find out the suitable nutrient management practice by producing maximum crop yields in calcareous soils of Bangladesh.

\section{Materials and Methods}

\subsection{Site Description and Soil}

Field experiments were conducted for consecutive two years in the farm of Regional Pulses Research Station, Bangladesh Agricultural Research Institute, located in the moist monsoon climatic subtropical region of Madaripur ( $23^{\circ} 10^{\prime} 53^{\prime \prime} \mathrm{N}$ latitude and $90^{\circ} 11^{\prime} 28^{\prime \prime} \mathrm{E}$ longitude) lies at an elevation of $7.0 \mathrm{~m}$ above the sea level.The calcareous soils of Madaripur, Bangladesh is medium high land with loamy textured belongs to Gopalpur series (Soil taxonomy: Aquic Eutrochrepts) under the Low Ganges River Floodplain (Agro-Ecological Zone-12). The area receives average annual rainfall varied from 17.2 to $833 \mathrm{~mm}$ of which maximum occurred from May to October. The mean maximum and minimum air temperatures during the period of the experiment were 11.6 and $36.7{ }^{\circ} \mathrm{C}$, respectively. Befor beginning the experiment initial soil $(0-15 \mathrm{~cm})$ samples have been analysed and chemical properties were viz. $\mathrm{pH} 7.3$, organic matter $1.41 \%$, total $\mathrm{N} 0.062 \%$, exchangeable $\mathrm{K} 0.16$ meq. $100 \mathrm{~g} \mathrm{~g}^{-1}$, available P $14.0 \mu \mathrm{g} \mathrm{g}^{-1}$, available S $17.0 \mu \mathrm{g} \mathrm{g}^{-1}$, available $\mathrm{Zn} 1.20 \mu \mathrm{g} \mathrm{g}^{-1}$ and available B $0.14 \mu \mathrm{g} \mathrm{g}^{-1}$.

\subsection{Experiment Arrangement}

The experiments were carried out over the three crop seasons such as Rabi (mid-October to mid-March), Kharif-I (mid-March to mid-June) and Kharif-II (mid-June to mid-October). 


\subsection{Experimental Treatment, Design and Management Procedure}

The experiment included three crops grown in a cycle, with four treatments for each crop viz. absolute nutrient controls $\left(\mathrm{T}_{1}\right)$; farmer's practice $\left(\mathrm{T}_{2}\right)$; AEZ based nutrient application $\left(\mathrm{T}_{3}\right)$ and soil test based nutrient application $\left(\mathrm{T}_{4}\right)$. Descriptions of the different treatments are given in Table 1.

Table 1. Rates of nutrients $\left(\mathrm{kg} \mathrm{ha}^{-1}\right)$ for mustard, mungbean and T. aman rice

\begin{tabular}{llll}
\hline Treatments & Mustard & Mungbean & T. aman rice \\
\hline $\mathrm{T}_{1}$ & Control & Control & Control \\
$\mathrm{T}_{2}$ & $\mathrm{~N}_{90} \mathrm{P}_{18} \mathrm{~K}_{15}$ & $\mathrm{~N}_{23} \mathrm{P}_{15} \mathrm{~K}_{8}$ & $\mathrm{~N}_{70} \mathrm{P}_{10} \mathrm{~K}_{15}$ \\
$\mathrm{~T}_{3}$ & $\mathrm{~N}_{60} \mathrm{P}_{12} \mathrm{~K}_{16} \mathrm{~S}_{10} \mathrm{Zn}_{1} \mathrm{~B}_{0.5}$ & $\mathrm{~N}_{15} \mathrm{P}_{18} \mathrm{~K}_{9} \mathrm{~S}_{8}$ & $\mathrm{~N}_{66} \mathrm{P}_{6} \mathrm{~K}_{12} \mathrm{~S}_{7} \mathrm{Zn}_{1}$ \\
$\mathrm{~T}_{4}$ & $\mathrm{~N}_{120} \mathrm{P}_{23} \mathrm{~K}_{70} \mathrm{~S}_{20} \mathrm{Zn}_{2} \mathrm{~B}_{2.5}$ & $\mathrm{~N}_{21} \mathrm{P}_{23} \mathrm{~K}_{30} \mathrm{~S}_{18} \mathrm{Zn}_{2} \mathrm{~B}_{1.5}$ & $\mathrm{~N}_{100} \mathrm{P}_{14} \mathrm{~K}_{66} \mathrm{~S}_{6} \mathrm{Zn}_{1.5} \mathrm{~B}_{1}$ \\
\hline
\end{tabular}

The experiment was laid out in randomized complete block design with three replications. The unit plot size was $4 \mathrm{~m} \times 3 \mathrm{~m}$ for all crops having the spacing of $30 \mathrm{~cm} \times 10 \mathrm{~cm}$ for mustard, $30 \mathrm{~cm} \times 10 \mathrm{~cm}$ for mungbean and 20 $\mathrm{cm} \times 15 \mathrm{~cm}$ for T. aman rice. The land was first opened by a tractor to a mean depth of 15 to $20 \mathrm{~cm}$ and prepared thoroughly by ploughing with a power tiller followed by laddering and leveling. The clods were broken and the fields were made weed and stubbles free. Besides the first crop, the plots were prepared every time by 4 to 5 spading keeping the same layout.

Full amount of fertilizers, except urea in mustard and rice was applied to respective plot during final land preparation and mixed thoroughly with soil by spading. Urea was applied in two equal split for mustard and three equal splits for T. aman rice. The sources of N, P, K, S, Zn and B were urea, triple super phosphate, muriate of potash, gypsum, zinc sulphate and boric acid, respectively.

The first crop mustard (var. BARI Mustard-14) were sown on mid November, $2^{\text {nd }}$ crop mungbean (BARI Mung-6) were sown end of March and the third crop T. aman rice (var. BRRI dhan-33) seedlings (30 days old) were transplanted mid July. Intercultural operations like irrigation, weeding and plant protection measures (insecticides and fungicides) were done as and when required. The transplanted rice seedlings were nursed properly in the seedbed. The crops were harvested after maturity.

\subsection{Data Collection and Analysis}

Data on yield contributing characters of all test crops were recorded from 10 randomly selected plants and 5 hills for rice from each plot. Data on yields $\left(\mathrm{kg} \mathrm{ha}^{-1}\right)$ were recorded from whole plot technique. Analysis of variance (ANOVA) for the yield and yield contributing characters and different nutrient content was done following the principle of F-statistics and the mean values were separated by Duncan's Multiple Range Test (DMRT) (K. A. Gomez \& A. A. Gomez, 1984) using MSTAT-C software.

\subsection{Soil and Plant Samples Analysis}

Soil samples at $0-15 \mathrm{~cm}$ were collected after completion of two cycles of the cropping system from each treatment plot. Plant samples (straw and grain) against each treatment plot were oven-dried at $70{ }^{\circ} \mathrm{C}$ for $48 \mathrm{~h}$ and finely ground.

The initial and final soil samples were analyzed for soil $\mathrm{pH}$ and organic matter by Nelson and Sommers (1982) method; total $\mathrm{N}$ by Microkjeldahl method (Bremner \& Mulvaney, 1982); exchangeable $\mathrm{K}$ by $1 \mathrm{~N} \mathrm{NH}_{4} \mathrm{OAc}$ method (Jackson, 1973); available P by Olsen and Sommers (1982) method; available S by turbidity method using $\mathrm{BaCl}_{2}$ (Fox et al., 1964); available $\mathrm{Zn}$ by DTPA method (Lindsay \& Norvell, 1978); available B by azomethine-H method (Page et al., 1982).

Ground plant samples were digested with di-acid mixture $\left(\mathrm{HNO}_{3}-\mathrm{HClO}_{4}\right)(5: 1)$ as described by Piper (1966) for the determination- concentration of $\mathrm{N}$ (Micro-Kjeldahl method), $\mathrm{P}$ (spectrophotometer method), $\mathrm{K}$ (atomic absorption spectrophotometer method), $\mathrm{S}$ (turbidity method using $\mathrm{BaCl}_{2}$ by spectrophotometer), $\mathrm{Zn}$ (atomic absorption spectrophotometer method) and B (spectrophotometer following azomethine-H method).

\subsection{Soil Solution, Rain and Irrigation Water Samples Analysis}

Soil solutions were collected at intervals of 15 days starting from the date after transplantation to harvest of rice crop with the help of $50 \mathrm{ml}$ plastic syringe and analyzed for determined nutrient leaching loss. The samples were brought to the laboratory immediately after collection, filtered through Whatman No. 42 filter paper and preserved for the determination of $\mathrm{P}, \mathrm{K}, \mathrm{S}, \mathrm{Zn}$ and $\mathrm{B}$. Rain water was collected by rain sampler after each rain 
event. Irrigation water was measured by V-Notch method (Khurmi, 1987). Collected rain and irrigation water were preserved for determining the nutrients (P, K, S, Zn and B). Soil solution, rain and irrigation water samples were analyzed for concentration of $\mathrm{P}, \mathrm{K}, \mathrm{S}, \mathrm{Zn}$ and B followed the same as plant samples analysis method.

\subsection{Hydraulic Conductivity Measurement}

We determined the saturated hydraulic conductivity in the laboratory by constant head method (Klute, 1965). Soil samples were collected from $0-15 \mathrm{~cm}$ depth using core samplers in triplicate. The hydraulic conductivity was calculated by using Darcy's equation as,

$$
\mathrm{K}_{\mathrm{w}}=-\frac{\mathrm{QL}}{\mathrm{AT} \Delta \mathrm{H}} \mathrm{cm} \mathrm{hr} \mathrm{r}^{-1}
$$

Where, $\mathrm{K}_{\mathrm{w}}=$ Saturated hydraulic conductivity $\left(\mathrm{cm} \mathrm{hr}^{-1}\right), \mathrm{A}=$ Cross sectional area of the sample in $\mathrm{cm}^{2}, \mathrm{~T}=\mathrm{Time}$ in minute, $\mathrm{Q}=$ Quantity of water $(\mathrm{ml})$ passing through the sample in time ' $\mathrm{T}$ ', $\mathrm{L}=$ Length of the sample in $\mathrm{cm}$, $\Delta \mathrm{H}=$ Hydraulic head difference (Length of sample+ height of water above the sample) in $\mathrm{cm}$.

\subsection{Nutrient Leaching Loss Estimation}

Nutrient loss was calculated from the results of percolation water and nutrient concentration in soil solution. In calculating percolation water $\left(\mathrm{L} \mathrm{m}^{-2}\right)$ the formula was given by Hanks and Ashcroft (1980):

$$
\mathrm{Q}=-\mathrm{K}_{\mathrm{w}} \mathrm{AT} \cdot \Delta \Psi_{\mathrm{h}} / \Delta \mathrm{z}
$$

Where, $\mathrm{Q}=$ Quantity of water, $\mathrm{K}_{\mathrm{w}}=$ Hydraulic conductivity, $\mathrm{A}=$ Area, $\mathrm{T}=$ Time, $\mathrm{H}=$ Difference in hydraulic potential and $\mathrm{Z}=$ Difference between two points taking 0 to downward as negative.The hydraulic potential was again calculated by adding the component potentials as $\Psi_{\mathrm{h}}=\Psi_{\mathrm{m}}+\Psi_{\mathrm{p}}+\Psi_{\mathrm{z}}$ where $\mathrm{h}, \mathrm{m}, \mathrm{p}$, and $\mathrm{z}$ represent hydraulic, metric, pressure and gravitational potentials. Negative Q was considered as downward movement of water.

\subsection{Nutrient Uptake and Apparent Balance Calculation}

Crop nutrient uptake was calculated from the nutrient (N, P, K, S, Zn and B) concentration and the straw and grain yields (Quayyum et al., 2002). Apparent nutrient balance for the mustard-mungbean-T. aman rice cropping system (average of two years) was computed as the difference between nutrient input and output (Paul et al., 2014). The inputs were supplied from (i) fertilizer (ii) rainfall (iii) irrigation water and the outputs were estimated from crop uptake and leaching loss in a cycle.

\subsection{Economic Analysis}

Added cost and added benefit were calculated. Besides, the gross return was calculated on the basis of different treatments which were directly related to the price of product. Cost of cultivation was involved with wage rate (land preparation, weeding, seed sowing and fertilizers application), pesticides, irrigation and fertilizers cost. Land used cost or rental value of land was not considered here. Marginal benefit cost ratio (MBCR) is the ratio of marginal or added benefit and cost. To compare different treatments combination with one control treatment the following equation was applied (Rahman et al., 2011).

$$
\begin{aligned}
\operatorname{MBCR}(\text { over control }) & =\frac{\operatorname{Gross} \text { return }\left(T_{i}\right)-\operatorname{Gross} \text { return }\left(T_{0}\right)}{\operatorname{VC}\left(T_{i}\right)-\operatorname{VC}\left(T_{0}\right)} \\
& =\frac{\text { Added benefit (over control) }}{\text { Added cost }(\text { over control) }}
\end{aligned}
$$

Where, $T_{i}=T_{2}, \ldots, T_{4}$ treatments; $T_{0}=$ Control treatment; $V C=$ Variable cost; and Gross return $=$ Yield $\times$ price.

\section{Result}

\subsection{Crops Yields}

Different nutrient management practices demonstrated significant effect on the grain and straw/stover yields of mustard, mungbean and T. aman rice in both the first and second years (Table 2). The highest grain yields of all test crops were found in the treatment $\mathrm{T}_{4}$. This was significantly higher than that of other treatments, except $\mathrm{T}_{3}$ treatment yield of $\mathrm{T}$. aman rice in first year which was stistically identical with $\mathrm{T}_{4}$. The second highest grain yield of mustard, mungbean and $T$. aman rice was obtained from the treatment $T_{3}$ which was significantly higher than that of $T_{2}$ and $T_{1}$. The performance of $T_{2}$ was again significantly higher than that of $T_{1}$ in both the years (Table 2). The grain yields (mean of two years) due to different nutrient management practices varied from 736 to $1530 \mathrm{~kg} \mathrm{ha}^{-1}$ in mustard, 970 to $1632 \mathrm{~kg} \mathrm{ha}^{-1}$ in mungbean and 3304 to $4729 \mathrm{~kg} \mathrm{ha}^{-1}$ in T. aman rice. In case of straw/stover yield, the treatments normally statistically differed with one another and significantly highest value was counted in $T_{4}$ treatment and lowest in $T_{1}$ treatment for all the test crops in both the years (Table 2). The 
percent grain yields of mustard, mungbean and T. aman rice increased over control due to different nutrient management practices were 50 to $108 \%, 22$ to $68 \%$ and 16 to $43 \%$, respectively (Figure 1). The majority of the yield contributing characters of mustard, mungbean and $\mathrm{T}$. aman rice are greatly responded to soil test based fertilization $\left(T_{4}\right)$ followed by AEZ based fertilization $\left(T_{3}\right)$ (data not present).

Table 2. Effect of nutrient management practices on grain and straw/stover yields of crops in mustard-mungbean-T. aman rice cropping system

\begin{tabular}{|c|c|c|c|c|c|c|}
\hline \multirow{2}{*}{ Treatments } & \multicolumn{3}{|c|}{ Grain yield $\left(\mathrm{kg} \mathrm{ha}^{-1}\right)$} & \multicolumn{3}{|c|}{ Straw/stover yield $\left(\mathrm{kg} \mathrm{ha}^{-1}\right)$} \\
\hline & $1^{\text {st }}$ year & $2^{\text {nd }}$ year & mean & $1^{\text {st }}$ year & $2^{\text {nd }}$ year & mean \\
\hline \multicolumn{7}{|l|}{ Mustard } \\
\hline Control $\left(\mathrm{T}_{1}\right)$ & $752 d$ & $720 d$ & 736 & $2007 d$ & $1917 d$ & 1962 \\
\hline F. practice $\left(\mathrm{T}_{2}\right)$ & $1100 \mathrm{c}$ & $1109 \mathrm{c}$ & 1104 & $2827 \mathrm{c}$ & $2847 \mathrm{c}$ & 2837 \\
\hline $\operatorname{AEZ}\left(\mathrm{T}_{3}\right)$ & $1264 b$ & $1300 \mathrm{~b}$ & 1284 & $3450 \mathrm{~b}$ & $3500 \mathrm{~b}$ & 3475 \\
\hline $\operatorname{STB}\left(\mathrm{T}_{4}\right)$ & $1512 \mathrm{a}$ & $1548 \mathrm{a}$ & 1530 & $4143 a$ & $4188 \mathrm{a}$ & 4166 \\
\hline $\mathrm{CV}(\%)$ & 3.60 & 4.11 & - & 2.65 & 3.25 & - \\
\hline $\mathrm{LSD}_{0.05}$ & 99.4 & 104 & - & 196 & 193 & - \\
\hline \multicolumn{7}{|l|}{ Mungbean } \\
\hline Control $\left(\mathrm{T}_{1}\right)$ & $1040 \mathrm{~d}$ & $900 \mathrm{~d}$ & 970 & $2231 d$ & $2122 d$ & 2177 \\
\hline F. practice $\left(T_{2}\right)$ & $1153 \mathrm{c}$ & $1222 \mathrm{c}$ & 1187 & $2323 \mathrm{c}$ & $2448 \mathrm{c}$ & 2386 \\
\hline $\operatorname{AEZ}\left(\mathrm{T}_{3}\right)$ & $1369 b$ & $1400 \mathrm{~b}$ & 1384 & $2501 \mathrm{~b}$ & $2546 \mathrm{~b}$ & 2524 \\
\hline $\operatorname{STB}\left(\mathrm{T}_{4}\right)$ & $1612 \mathrm{a}$ & $1651 \mathrm{a}$ & 1632 & $2710 \mathrm{a}$ & $2742 a$ & 2726 \\
\hline CV (\%) & 3.10 & 3.72 & - & 3.85 & 3.45 & - \\
\hline $\mathrm{LSD}_{0.05}$ & 225 & 267 & - & 236 & 215 & - \\
\hline \multicolumn{7}{|l|}{ T. aman rice } \\
\hline Control $\left(\mathrm{T}_{1}\right)$ & $3358 \mathrm{c}$ & $3250 \mathrm{~d}$ & 3304 & $3449 \mathrm{c}$ & $3301 d$ & 3375 \\
\hline F. practice $\left(T_{2}\right)$ & $3812 b$ & $3847 \mathrm{c}$ & 3829 & $3936 b$ & $4031 \mathrm{c}$ & 3983 \\
\hline $\operatorname{AEZ}\left(\mathrm{T}_{3}\right)$ & $4269 a$ & $4278 b$ & 4273 & $4394 a$ & $4408 b$ & 4401 \\
\hline $\operatorname{STB}\left(\mathrm{T}_{4}\right)$ & $4692 a$ & $4766 a$ & 4729 & $4847 \mathrm{a}$ & $4955 \mathrm{a}$ & 4901 \\
\hline CV (\%) & 4.27 & 3.20 & - & 4.33 & 3.24 & - \\
\hline $\mathrm{LSD}_{0.05}$ & 515 & 312 & - & 523 & 326 & - \\
\hline
\end{tabular}

Note. Values within the same column with a common letter do not differ significantly $(\mathrm{P}<0.05)$.

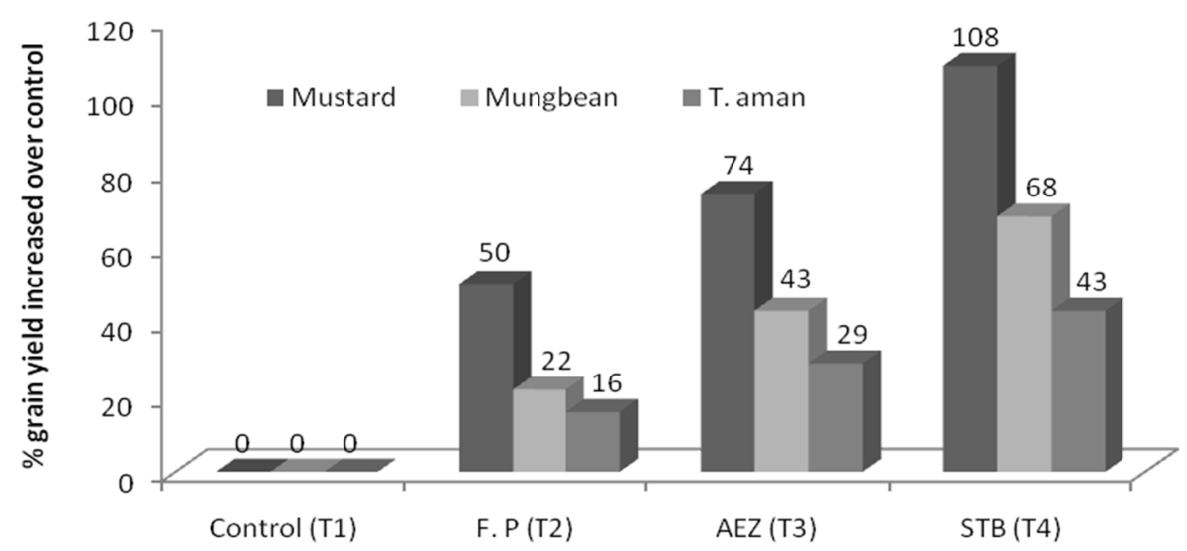

Figure 1. Treatment wise percent grain yield increased over control for the crops of mustard-mungbean-T. aman rice cropping system 


\subsection{Nutrient Concentration and Defficiency Detection}

Grain nutrient concentration (mean of two years) of test crops-mustard, mungbean and T. aman rice and published mean nutrient critical limits are presented in Table 3. The nutrients concentration of mustard showed variation due to different nutrient management practices from 2.95 to $3.29 \% \mathrm{~N}, 0.400$ to $0.460 \% \mathrm{P}, 0.800$ to $0.845 \% \mathrm{~K}, 0.801$ to $0.835 \% \mathrm{~S}, 32.4$ to $34.7 \mathrm{ppm} \mathrm{Zn}$ and 21.1 to $22.7 \mathrm{ppm} \mathrm{B}$. Different nutrient treatments contributed to change the grain nutrient concentration in mungbean viz. 3.14 to $3.26 \% \mathrm{~N}, 0.240$ to $0.285 \% \mathrm{P}$, 1.25 to $1.32 \% \mathrm{~K}, 0.12$ to $0.15 \% \mathrm{~S}, 24.7$ to $29.0 \mathrm{ppm} \mathrm{Zn}$ and 16.3 to $17.7 \mathrm{ppm}$ B. Similarly in T. aman rice, concentration ranged from 1.43 to $1.59 \% \mathrm{~N}, 0.175$ to $0.210 \% \mathrm{P}, 0.225$ to $0.275 \% \mathrm{~K}, 0.065$ to $0.085 \% \mathrm{~S}, 40.5$ to $41.6 \mathrm{ppm} \mathrm{Zn}$ and 23.0 to $26.6 \mathrm{ppm} \mathrm{B}$. Results revealed that $\mathrm{N}$ deficiency was detected in mustard, mungbean and $\mathrm{T}$. aman rice in all the treatment where severe $\mathrm{N}$ deficiency to be noted in $\mathrm{T}$. aman rice. Comparison of $\mathrm{N}$ concentration in all test crops between critical $\mathrm{N}$ value among the treatment, lowest $\mathrm{N}$ deficiency found in $\mathrm{T}_{4}$ treatment (Table 3). There was no P deficiency in mustard but mungbean and rice crop was showed minor deficency due to different treatment. Severe $\mathrm{K}$ deficiency detected in mustard and $\mathrm{T}$. aman rice, but in mungbean showed minor $\mathrm{K}$ deficiency in all the treatment. The highest $\mathrm{K}$ deficiency was estimated from $\mathrm{T}_{1}$ and lowest from $\mathrm{T}_{4}$ treatment in all test crops (Table 3). Different treatment showed sufficiency of $\mathrm{S}$ in mustard, deficiency of $\mathrm{S}$ in mungbean and $\mathrm{T}$. aman rice. All the treatment shows evidence of $\mathrm{Zn}$ deficiency in all test crops of this system. Mustard and mungbean showed deficiency of B in all the treatments while the highest B deficiency found in $\mathrm{T}_{1}$ and lowest in $\mathrm{T}_{4}$ treatment. The $3^{\text {rd }}$ crop $\mathrm{T}$. aman rice crops showed $\mathrm{B}$ sufficiency in all the treatments (Table 3).

Table 3. Comparison between the grain nutrients concentration of mustard, mungbean and $\mathrm{T}$. aman with nutrients critical limit due to different nutrient management practices

\begin{tabular}{lllllll}
\hline Treatment & $\mathrm{N}$ & $\mathrm{P}$ & $\mathrm{K}$ & $\mathrm{S}$ & $\mathrm{Zn}$ & $\mathrm{B}$ \\
\hline Mustard & $-\cdots$ & & & & \\
Control $\left(\mathrm{T}_{1}\right)$ & & & & & \\
F. practice $\left(\mathrm{T}_{2}\right)$ & 3.95 & 0.400 & 0.800 & 0.801 & 32.4 & 21.1 \\
AEZ $\left(\mathrm{T}_{3}\right)$ & 3.11 & 0.430 & 0.825 & 0.810 & 32.4 & 21.3 \\
STB $\left(\mathrm{T}_{4}\right)$ & 3.15 & 0.445 & 0.835 & 0.835 & 34.3 & 22.3 \\
Critical value & 3.29 & 0.460 & 0.845 & 0.835 & 34.7 & 22.7 \\
\hline Mungbean & 3.60 & 0.25 & 1.60 & 0.13 & 50.0 & 30.0 \\
Control $\left(\mathrm{T}_{1}\right)$ & & & & & & \\
F. practice $\left(\mathrm{T}_{2}\right)$ & 3.14 & 0.240 & 1.25 & 0.12 & 24.7 & 16.3 \\
AEZ $\left(\mathrm{T}_{3}\right)$ & 3.18 & 0.260 & 1.29 & 0.13 & 25.0 & 16.4 \\
STB $\left(\mathrm{T}_{4}\right)$ & 3.21 & 0.275 & 1.31 & 0.13 & 26.8 & 17.2 \\
Critical value & 3.26 & 0.285 & 1.32 & 0.15 & 29.0 & 17.7 \\
T. aman rice & 3.63 & 0.26 & 1.75 & 0.20 & 35.0 & 27.0 \\
Control $\left(\mathrm{T}_{1}\right)$ & & & & & & \\
F. practice $\left(\mathrm{T}_{2}\right)$ & 1.43 & 0.175 & 0.225 & 0.065 & 40.5 & 23.0 \\
AEZ $\left(\mathrm{T}_{3}\right)$ & 1.49 & 0.190 & 0.245 & 0.075 & 40.5 & 23.4 \\
STB $\left(\mathrm{T}_{4}\right)$ & 1.55 & 0.205 & 0.265 & 0.080 & 41.5 & 25.5 \\
Critical value & 1.59 & 0.210 & 0.275 & 0.085 & 41.6 & 26.6 \\
\hline
\end{tabular}

Note. Nutrient critical values source: Kalra (1998); Bell and Kovar (2000); Plant Analysis Handbook (2017), Grain Legume Handbook (2017).

\subsection{Nutrient Uptake}

Different nutrient management practices demonstrated significantly to uptake of N, P, K, S, Zn and B by the crops of mustard-mungbean-T. aman rice cropping system in both first and second years (Table 4). The greatest uptakes of all nutrients were estimated from $\mathrm{T}_{4}$ treatment by all the test crops which were significantly different over the other treatments but some exception existed. The nutrient uptake followed the order: $\mathrm{N}>\mathrm{K}>\mathrm{S}>\mathrm{P}>$ $\mathrm{Zn}>\mathrm{B}$. Control $\left(\mathrm{T}_{1}\right)$ treatment showed significantly inferior nutrient uptake to the others treatment (Table 4). The total nutrients uptake by crops (mustard+mungbean+T. aman) varied from 162-296 kg N ha ${ }^{-1}, 16.8-32.1 \mathrm{~kg}$ 
$\mathrm{P} \mathrm{ha}^{-1}, 150-248 \mathrm{~kg} \mathrm{~K} \mathrm{ha}^{-1}, 17.3-36.2 \mathrm{~kg} \mathrm{~S} \mathrm{ha}^{-1}, 0.45-0.74 \mathrm{~kg} \mathrm{Zn} \mathrm{ha}^{-1}$ and $0.25-0.44 \mathrm{~kg} \mathrm{~B} \mathrm{ha}^{-1}$. Among the treatments, maximum total nutrients uptake were recorded from $\mathrm{T}_{4}$ followed by AEZ based treatment $\left(\mathrm{T}_{3}\right)$ and the minimum was in control treatment (Figures 2 and 3).

Table 4. Effect of nutrient management practices on nutrient uptake by mustard-mungbean-T. aman (grain+straw/stover) cropping system

\begin{tabular}{|c|c|c|c|c|c|c|c|c|c|c|c|c|}
\hline \multirow{2}{*}{ Treatment } & \multicolumn{2}{|c|}{$\mathbf{N}$} & \multicolumn{2}{|c|}{$\mathbf{P}$} & \multicolumn{2}{|c|}{$\mathbf{K}$} & \multicolumn{2}{|c|}{$\mathbf{S}$} & \multicolumn{2}{|c|}{$\mathbf{Z n}$} & \multicolumn{2}{|c|}{ B } \\
\hline & $1^{\text {st }} \mathrm{yr}$ & $2^{\text {nd }} \mathrm{yr}$ & $1^{\text {st }} \mathrm{yr}$ & $2^{\text {nd }} \mathrm{yr}$ & $1^{\text {st }} \mathrm{yr}$ & $2^{\text {nd }} \mathrm{yr}$ & $1^{\text {st }} \mathrm{yr}$ & $2^{\text {nd }} \mathrm{yr}$ & $1^{\text {st }} \mathrm{yr}$ & $2^{\text {nd }} \mathrm{yr}$ & $1^{\text {st }} \mathrm{yr}$ & $2^{\text {nd }} \mathrm{yr}$ \\
\hline & \multicolumn{12}{|c|}{ - } \\
\hline \multicolumn{13}{|c|}{ 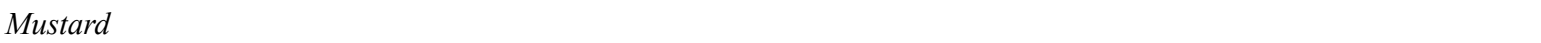 } \\
\hline Control $\left(\mathrm{T}_{1}\right)$ & $40.6 \mathrm{~d}$ & $36.2 \mathrm{~d}$ & $3.69 \mathrm{~d}$ & $3.19 \mathrm{~d}$ & $35.8 \mathrm{~d}$ & $33.9 \mathrm{~d}$ & $10.3 \mathrm{~d}$ & $9.52 \mathrm{~d}$ & $0.08 \mathrm{~d}$ & $0.07 \mathrm{~d}$ & $0.04 \mathrm{c}$ & $0.04 \mathrm{c}$ \\
\hline F. practice $\left(\mathrm{T}_{2}\right)$ & $62.6 \mathrm{c}$ & $62.0 \mathrm{c}$ & $5.97 \mathrm{c}$ & $5.51 \mathrm{c}$ & $51.5 \mathrm{c}$ & $52.1 \mathrm{c}$ & $15.3 \mathrm{c}$ & $15.4 \mathrm{c}$ & $0.11 \mathrm{c}$ & $0.11 \mathrm{c}$ & $0.06 \mathrm{~b}$ & $0.06 \mathrm{~b}$ \\
\hline $\operatorname{AEZ}\left(\mathrm{T}_{3}\right)$ & $77.8 \mathrm{~b}$ & $77.9 \mathrm{~b}$ & $7.07 \mathrm{~b}$ & $6.77 b$ & $62.7 \mathrm{~b}$ & $64.0 \mathrm{~b}$ & $18.1 \mathrm{~b}$ & $19.0 \mathrm{~b}$ & $0.14 b$ & $0.14 b$ & $0.07 \mathrm{~b}$ & $0.08 \mathrm{a}$ \\
\hline $\operatorname{STB}\left(\mathrm{T}_{4}\right)$ & $99.6 \mathrm{a}$ & $99.2 \mathrm{a}$ & $9.19 \mathrm{a}$ & $8.65 a$ & $76.7 \mathrm{a}$ & $77.1 \mathrm{a}$ & $22.2 \mathrm{a}$ & $22.9 \mathrm{a}$ & $0.17 \mathrm{a}$ & $0.18 \mathrm{a}$ & $0.09 \mathrm{a}$ & $0.10 \mathrm{a}$ \\
\hline CV $(\%)$ & 2.91 & 2.71 & 7.66 & 8.39 & 4.63 & 2.77 & 3.07 & 3.02 & 6.53 & 4.08 & 9.56 & 8.55 \\
\hline $\mathrm{LSD}_{0.05}$ & 4.08 & 3.36 & 0.99 & 1.01 & 5.25 & 3.01 & 1.01 & 1.01 & 0.02 & 0.02 & 0.02 & 0.02 \\
\hline \multicolumn{13}{|l|}{ Mungbean } \\
\hline Control $\left(\mathrm{T}_{1}\right)$ & $60.2 \mathrm{~d}$ & $53.5 \mathrm{~d}$ & $6.39 \mathrm{c}$ & $5.25 \mathrm{c}$ & $45.6 \mathrm{~d}$ & $41.7 \mathrm{~d}$ & $3.14 \mathrm{~d}$ & $2.48 \mathrm{c}$ & $0.07 \mathrm{~b}$ & $0.06 \mathrm{~b}$ & $0.06 \mathrm{~b}$ & $0.06 \mathrm{~b}$ \\
\hline F.practice $\left(\mathrm{T}_{2}\right)$ & $66.3 \mathrm{c}$ & $69.3 \mathrm{c}$ & $7.53 b c$ & $7.22 b$ & $49.4 \mathrm{c}$ & $51.4 \mathrm{c}$ & $3.70 \mathrm{c}$ & $3.42 \mathrm{~b}$ & $0.08 \mathrm{~b}$ & $0.07 b$ & $0.07 \mathrm{ab}$ & $0.07 \mathrm{~b}$ \\
\hline $\operatorname{AEZ}\left(\mathrm{T}_{3}\right)$ & $76.2 b$ & $77.4 \mathrm{~b}$ & $8.59 b$ & $8.36 \mathrm{ab}$ & $55.6 \mathrm{~b}$ & $55.9 \mathrm{~b}$ & $4.17 b$ & $3.46 \mathrm{~b}$ & $0.09 b$ & $0.10 \mathrm{a}$ & $0.08 \mathrm{ab}$ & $0.09 \mathrm{ab}$ \\
\hline $\operatorname{STB}\left(\mathrm{T}_{4}\right)$ & $89.1 \mathrm{a}$ & $90.4 a$ & $10.1 \mathrm{a}$ & $9.56 \mathrm{a}$ & $62.4 \mathrm{a}$ & $62.8 \mathrm{a}$ & $5.29 a$ & $4.51 \mathrm{a}$ & $0.11 \mathrm{a}$ & $0.12 \mathrm{a}$ & $0.09 \mathrm{a}$ & $0.10 \mathrm{a}$ \\
\hline CV (\%) & 2.74 & 2.07 & 7.08 & 8.10 & 2.81 & 2.62 & 2.14 & 5.58 & 5.71 & 8.19 & 8.18 & 7.70 \\
\hline $\mathrm{LSD}_{0.05}$ & 3.53 & 3.01 & 1.15 & 1.02 & 2.99 & 3.23 & 0.32 & 0.38 & 0.02 & 0.03 & 0.02 & 0.02 \\
\hline \multicolumn{13}{|l|}{ T. aman rice } \\
\hline Control $\left(\mathrm{T}_{1}\right)$ & $70.4 \mathrm{~d}$ & $64.0 \mathrm{~d}$ & $8.11 \mathrm{~d}$ & $6.85 \mathrm{c}$ & $72.9 \mathrm{~d}$ & $69.2 \mathrm{~d}$ & $5.45 \mathrm{c}$ & $3.64 d$ & $0.32 \mathrm{~d}$ & $0.30 \mathrm{~d}$ & $0.15 \mathrm{~d}$ & $0.14 \mathrm{~d}$ \\
\hline F.practice $\left(\mathrm{T}_{2}\right)$ & $82.4 \mathrm{c}$ & $80.7 \mathrm{c}$ & $10.4 \mathrm{c}$ & $8.94 b$ & $84.3 \mathrm{c}$ & $87.0 \mathrm{c}$ & $6.20 c$ & $5.11 \mathrm{c}$ & $0.36 \mathrm{c}$ & $0.37 \mathrm{c}$ & $0.18 \mathrm{c}$ & $0.18 \mathrm{c}$ \\
\hline $\operatorname{AEZ}\left(\mathrm{T}_{3}\right)$ & $94.7 b$ & $92.3 b$ & $12.5 b$ & $11.6 \mathrm{a}$ & $95.1 \mathrm{~b}$ & $96.6 \mathrm{~b}$ & $7.80 \mathrm{~b}$ & $6.52 b$ & $0.41 \mathrm{~b}$ & $0.41 b$ & $0.20 \mathrm{~b}$ & $0.2 \mathrm{lb}$ \\
\hline $\operatorname{STB}\left(\mathrm{T}_{4}\right)$ & $109 a$ & $108 \mathrm{a}$ & $14.2 \mathrm{a}$ & $12.5 \mathrm{a}$ & $106 a$ & $110 \mathrm{a}$ & $9.07 \mathrm{a}$ & $8.27 \mathrm{a}$ & $0.45 \mathrm{a}$ & $0.46 \mathrm{a}$ & $0.24 \mathrm{a}$ & $0.25 \mathrm{a}$ \\
\hline CV $(\%)$ & 2.99 & 2.01 & 4.44 & 4.99 & 2.32 & 2.62 & 7.94 & 8.41 & 4.43 & 4.44 & 5.56 & 4.85 \\
\hline $\mathrm{LSD}_{0.05}$ & 3.75 & 3.46 & 1.00 & 1.00 & 3.35 & 4.76 & 1.13 & 1.00 & 0.03 & 0.02 & 0.03 & 0.02 \\
\hline
\end{tabular}

Note. Values within the same column with a common letter do not differ significantly $(\mathrm{P}<0.05)$.

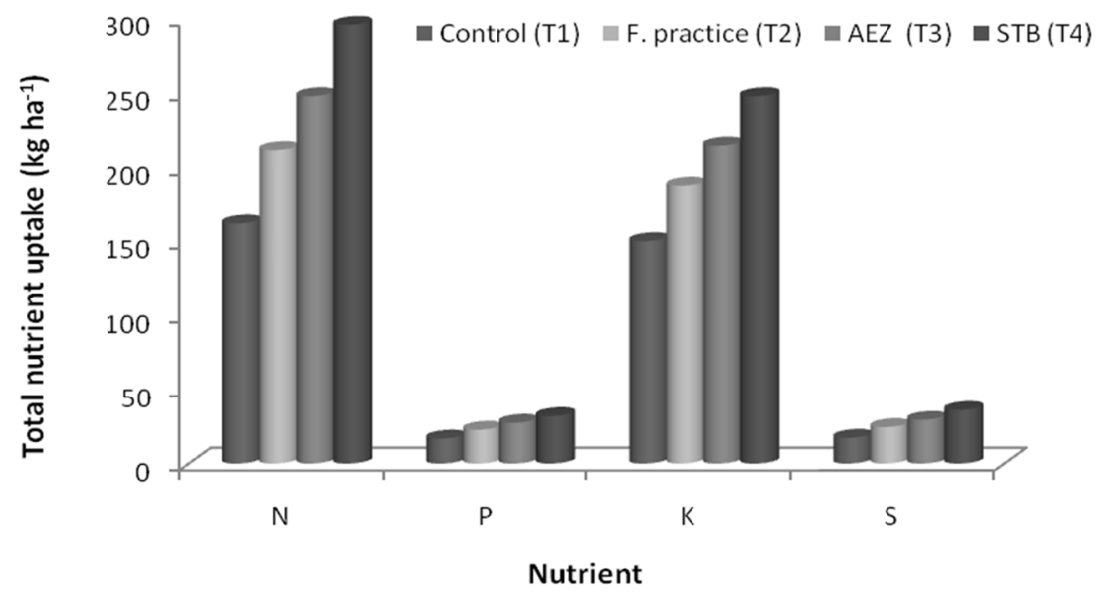

Figure 2. Effect of nutrient management practices on total uptake of nutrients by crops under mustard-mungbean-T. aman cropping system 


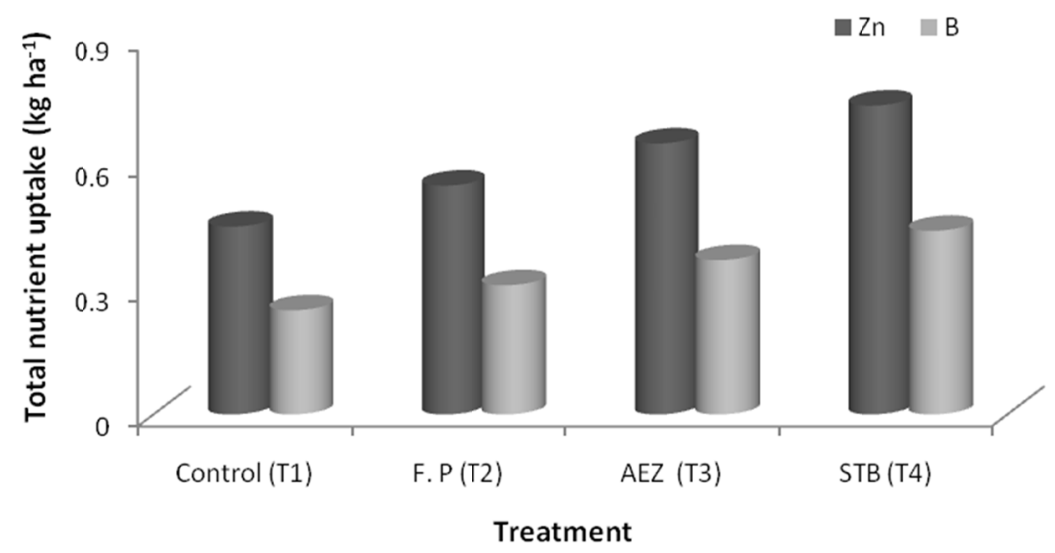

Figure 3. Effect of nutrient management practices on total uptake of zinc and boron by crops under mustard-mungbean-T. aman cropping system

\subsection{Leaching of Nutrients}

Leaching loss was estimated only to T. aman rice. Due to dry land condition, leaching loss was not considered during mustard and mungbean cultivation. Nutrient loss was calculated from the results of percolation water and nutrient concentration in soil solution. Nitrogen loss was ignored due to very low concentration in soil solution. Two closest mean nutrient concentrations in soil solution samples were considered. Nutrient leaching is the downword movement of dissolved nutrients in the soil profile with percolating water (Lehmann \& Schroth, 2003). Different nutrient management practices contributed significantly to losses of nutrients viz. P, K, S, Zn and B through leaching in both the years (Table 5). In most of the cases, the highest nutrients losses were monitored and recorded in the $T_{4}$ followed by $T_{3}$ treatment. The lowest loss was found in $\left(T_{1}\right)$ treatment (Table 5).

Our observation on nutrient losses depend on many factors-water soluble nutrient concentration is one of them. Application rates of fertilizers might be maintained soluble nutrient concentration hence $\mathrm{T}_{4}$ treatment exhibited comperatively higher nutrient losses. Talele et al. (1993) reported that the soil solution nutrients (K) concentration increased after nutrients $(\mathrm{K})$ addition. But the concentration of $\mathrm{K}$ and other nutrient in soil solution decreased during the growth period due to uptake by rice plants (Filep, 2002). Yamakawa et al. (2004) corroborated that nutrient $(\mathrm{P}, \mathrm{K}, \mathrm{S}, \mathrm{Zn}$ and $\mathrm{B})$ concentration in soil solution gradually decreased before panicle initiation.

The amount of nutrients loss (mean of two years) through leaching varied from 0.24 to $0.59 \mathrm{~kg} \mathrm{P} \mathrm{ha}{ }^{-1}, 2.73$ to $9.88 \mathrm{~kg}$ $\mathrm{K} \mathrm{ha}^{-1}, 1.52$ to $3.53 \mathrm{~kg} \mathrm{Sha}^{-1}, 0.04-0.12 \mathrm{~kg} \mathrm{Zn} \mathrm{ha}^{-1}$ and $0.07-0.29 \mathrm{~kg} \mathrm{~B} \mathrm{ha}^{-1}$ (Table not present).

Table 5. Effect of nutrient management practices on loss of nutrients through leaching under mustard-mungbean-T. aman rice cropping system

\begin{tabular}{|c|c|c|c|c|c|c|c|c|c|c|}
\hline \multirow{2}{*}{ Treatment } & \multicolumn{2}{|c|}{$\mathrm{P}$} & \multicolumn{2}{|c|}{$\mathrm{K}$} & \multicolumn{2}{|r|}{$\mathrm{S}$} & \multicolumn{2}{|r|}{$\mathrm{Zn}$} & \multicolumn{2}{|c|}{ B } \\
\hline & $1^{\text {st }} \mathrm{yr}$ & $2^{\text {nd }} y r$ & $1^{\mathrm{st}} \mathrm{yr}$ & $2^{\text {nd }} \mathrm{yr}$ & $1^{\mathrm{st}} \mathrm{yr}$ & $2^{\text {nd }} y r$ & $1^{\text {st }} \mathrm{yr}$ & $2^{\text {nd }} \mathrm{yr}$ & $1^{\text {st }} \mathrm{yr}$ & $2^{\text {nd }} \mathrm{yr}$ \\
\hline & $\begin{array}{ll}----\cdot \\
\end{array}$ & ----- & 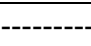 & --- & - & $\mathrm{g} \mathrm{ha}^{-1}$ & & & 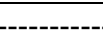 & ------ \\
\hline Control $\left(\mathrm{T}_{1}\right)$ & $0.24 \mathrm{~d}$ & $0.23 \mathrm{~d}$ & $2.77 \mathrm{~d}$ & $2.68 \mathrm{~d}$ & $1.59 \mathrm{c}$ & $1.44 \mathrm{c}$ & $0.04 \mathrm{~b}$ & $0.04 b$ & $0.07 \mathrm{~b}$ & $0.07 \mathrm{c}$ \\
\hline F. practice $\left(\mathrm{T}_{2}\right)$ & $0.51 \mathrm{c}$ & $0.49 \mathrm{c}$ & $7.34 \mathrm{c}$ & $7.13 \mathrm{c}$ & $2.75 b$ & $2.68 b$ & $0.04 b$ & $0.04 \mathrm{~b}$ & $0.07 \mathrm{~b}$ & $0.07 \mathrm{c}$ \\
\hline $\operatorname{AEZ}\left(\mathrm{T}_{3}\right)$ & $0.56 \mathrm{~b}$ & $0.55 \mathrm{~d}$ & $9.45 b$ & $9.18 \mathrm{~b}$ & $3.35 \mathrm{ab}$ & $3.27 \mathrm{ab}$ & $0.10 \mathrm{a}$ & $0.10 \mathrm{ab}$ & $0.25 \mathrm{ab}$ & $0.25 b$ \\
\hline $\operatorname{STB}\left(\mathrm{T}_{4}\right)$ & $0.59 \mathrm{a}$ & $0.58 \mathrm{a}$ & $10.0 \mathrm{a}$ & $9.76 \mathrm{a}$ & $3.53 \mathrm{a}$ & $3.52 \mathrm{a}$ & $0.11 \mathrm{a}$ & $0.12 \mathrm{a}$ & $0.28 \mathrm{a}$ & $0.29 a$ \\
\hline CV $(\%)$ & 2.97 & 3.10 & 2.88 & 2.76 & 6.98 & 7.31 & 6.4 & 5.95 & 6.7 & 5.4 \\
\hline $\mathrm{LSD}_{0.05}$ & 0.032 & 0.04 & 1.10 & 1.00 & 0.89 & 0.96 & 0.019 & 0.02 & 0.02 & 0.02 \\
\hline
\end{tabular}

Note. Values within the same column with a common letter do not differ significantly $(\mathrm{P}<0.05)$. 


\subsection{Nutrients Added through Rain Water}

Table 6 demonstrated the data of nutrient concentration and amount of nutrients addition to soil through rain water during Rabi, Kharif-I and Kharif-II (T. aman rice) seasons. The concentrations of P, K, S, Zn and B in rain water during Rabi season were estimated of $0.05,1.04,0.81,0.010$ and $0.06 \mathrm{mg} \mathrm{L}^{-1}$, respectively. The concentration of $\mathrm{P}, \mathrm{K}, \mathrm{S}, \mathrm{Zn}$ and $\mathrm{B}$ during Kharif-I season were recorded $0.06,1.05,0.82,0.011$ and $0.07 \mathrm{mg} \mathrm{L}^{-1}$, respectively in rain water. Again, the concentrations of $\mathrm{P}, \mathrm{K}, \mathrm{S}, \mathrm{Zn}$ and $\mathrm{B}$ in rain water during Kharif-II (T. aman rice) season were estimated $0.04,0.61,0.31,0.004$ and $0.04 \mathrm{mg} \mathrm{L}^{-1}$, respectively. Furthermore, addition amount of P, K, S, Zn and B to the soil of $0.001,0.017,0.013,0.0002$ and $0.001 \mathrm{~kg} \mathrm{ha}^{-1}$, respectively during Rabi season. The addition amount of $\mathrm{P}, \mathrm{K}, \mathrm{S}, \mathrm{Zn}$ and $\mathrm{B}$ to the soil of $0.02,0.43,0.34,0.005$ and $0.03 \mathrm{~kg} \mathrm{ha}^{-1}$, respectively during Kharif-I. In case of Kharif-II (T. aman rice) season the addition amount of P, K, S, Zn and B to the soil of $0.15,2.79,1.42,0.016$ and $0.16 \mathrm{~kg} \mathrm{ha}^{-1}$, respectively (Table 6).

Observation from the results of nutrient concentrations during Rabi and Kharif-I was almost samilar but found lower in Kharif-II (T. aman rice) season. The Rabi season was more or less rain free or sometimes small rainfall (0-3.20 mm) occurred during this period. The rainfall increase in Kharif-I season and tremendously increase in T. aman rice season over Rabi season (data not present). During the Rabi season the sky remain clear and the air also remain free of dust due to the after effect of post monsoon period. During the Kharif-I period the wind speed increases after winter which makes the air dirty through the windblown dust particles. The emitted dust particles increase the chemical composition (high nutrient concentration) of precipitation (Gllles et al., 1989; Andreae et al., 1990). Though the nutrient concentration was lower in Kharif-II but the precipitation increased tremendously hence the Table 6 appeared increase addition amount of nutrients to soil.

Table 6. Nutrients concentration in rain water and addition to soil during Rabi, Kharif-I and Kharif-II (T. aman rice) seasons under mustard-mungbean-T. aman rice cropping system (mean of two years)

\begin{tabular}{|c|c|c|c|c|c|}
\hline Growing seasons & $\mathrm{P}$ & $\mathrm{K}$ & $\mathrm{S}$ & $\mathrm{Zn}$ & $\mathrm{B}$ \\
\hline Concentration & \multicolumn{5}{|c|}{ 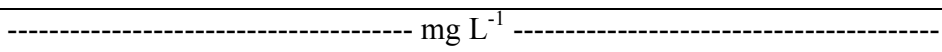 } \\
\hline Rabi & 0.05 & 1.04 & 0.81 & 0.010 & 0.06 \\
\hline Kharif-I & 0.06 & 1.05 & 0.82 & 0.011 & 0.07 \\
\hline Kharif-II (T. aman rice) & 0.04 & 0.61 & 0.31 & 0.004 & 0.04 \\
\hline \multicolumn{6}{|l|}{ Addition } \\
\hline Rabi & 0.001 & 0.017 & 0.013 & 0.0002 & 0.001 \\
\hline Kharif-I & 0.02 & 0.43 & 0.34 & 0.005 & 0.03 \\
\hline Kharif-II (T. aman rice) & 0.15 & 2.79 & 1.42 & 0.016 & 0.16 \\
\hline
\end{tabular}

\subsection{Nutrients Added through Irrigation Water}

Laboratory analysis of irrigation water results on concentrations of $\mathrm{P}, \mathrm{K}, \mathrm{S}, \mathrm{Zn}$ and B were $0.24,1.70,0.93,0.035$ and $0.09 \mathrm{mg} \mathrm{L}^{-1}$, respectively (Table 7). Nitrogen concentration ignored due to low concentration in irrigation water. Researchers stated different nutrient concentrations of irrigation water viz. Saleque et al. (2006) reported that mean $\mathrm{P}$ concentrations in irrigation water for the three sites were $0.12,0.10$, and $0.03 \mathrm{mg} \mathrm{L}^{-1}$, respectively. The mean $\mathrm{K}$ concentrations in irrigation water for the three sites were $1.06,2.39$, and $1.06 \mathrm{mg} \mathrm{L}^{-1}$ (Panaullah et al., 2006). Rashid (2005) reported that the $\mathrm{Zn}$ and $\mathrm{B}$ cocentrations ranged from 0.025 to $0.049 \mathrm{mg} \mathrm{L}^{-1}$ and 0.02 to $0.095 \mathrm{mg} \mathrm{L}^{-1}$, respectively in ground irrigation water. Addition amounts of $\mathrm{P}, \mathrm{K}, \mathrm{S}, \mathrm{Zn}$ and $\mathrm{B}$ to the experimental plot were observed $0.38,2.75,1.49,0.055$ and $0.15 \mathrm{~kg} \mathrm{ha}^{-1}$, respectively (Table 7). Abedin et al. (1991) stated that addition of $\mathrm{P}, \mathrm{K}, \mathrm{S}$ and $\mathrm{Zn}$ were $0.22,18.7,6.16$ and $0.022 \mathrm{~kg} \mathrm{ha}^{-1}$, respectively through irrigation in rice field of Bangladesh.

Table 7. Nutrients concentration in irrigation water and addition to soil during Kharif-II (T. aman rice) seasons under mustard-mungbean- $\mathrm{T}$. aman rice cropping system (mean of two years)

\begin{tabular}{|c|c|c|c|c|c|c|}
\hline Growing seasons & & $\mathrm{P}$ & $\mathrm{K}$ & $\mathrm{S}$ & $\mathrm{Zn}$ & B \\
\hline \multirow{3}{*}{ Kharif-II (T. aman rice) } & & 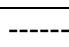 & $-\cdots$ & $---m$ & ------- & ------- \\
\hline & Concentration & 0.24 & 1.70 & 0.93 & 0.035 & 0.09 \\
\hline & Addition & 0.38 & 2.75 & 1.49 & 0.055 & 0.15 \\
\hline
\end{tabular}




\subsection{Total Input and Output of Nutrients}

The input of nutrient mainly from fertilizer but in this estimate, the nutrients in rainfall and irrigation water were considered. Biological nitrogen fixation (BNF) was not considerd. Annual input of $\mathrm{N}$ varied from 0.00 to $241 \mathrm{~kg}$ $\mathrm{ha}^{-1} \mathrm{yr}^{-1}, \mathrm{P}$ input ranged from 0.55 to $60.6 \mathrm{~kg} \mathrm{ha}^{-1} \mathrm{yr}^{-1}$, and $\mathrm{K}$ input was from 5.98 to $172 \mathrm{~kg} \mathrm{ha}^{-1} \mathrm{yr}^{-1}$. The S input varied from 3.26 to $47.3 \mathrm{~kg} \mathrm{ha}^{-1} \mathrm{yr}^{-1}$ and input of $\mathrm{Zn}$ varied from 0.076 to $5.58 \mathrm{~kg} \mathrm{ha}^{-1} \mathrm{yr}^{-1}$. Boron input was estimated 0.34 to $5.34 \mathrm{~kg} \mathrm{ha}^{-1} \mathrm{yr}^{-1}$. The great amounts of nutrient were measured in $\mathrm{T}_{4}$ treatment and tine amount in $\mathrm{T}_{1}$ treatment (Table 8 ).

The output of nutrients (mean of two years) ranged from 162 to $296 \mathrm{~kg} \mathrm{~N} \mathrm{ha}^{-1}, 18.0$ to $33.0 \mathrm{~kg} \mathrm{P} \mathrm{ha}^{-1}, 153$ to 258 $\mathrm{kg} \mathrm{K} \mathrm{ha}{ }^{-1}, 18.8$ to $39.7 \mathrm{~kg} \mathrm{~S} \mathrm{ha}^{-1}, 0.49$ to $0.86 \mathrm{~kg} \mathrm{Zn} \mathrm{ha}^{-1}$ and 0.32 to $0.73 \mathrm{~kg} \mathrm{~B} \mathrm{ha}^{-1}$. The highest outputs of all nutrients were found in $\mathrm{T}_{4}$ and the lowest were in control $\left(\mathrm{T}_{1}\right)$ treatment (Table 8).

Table 8. Effect of different nutrient management practices on nutrients input (added from fertilizer, ranfall \& irrigation) and output (crops uptake \& leaching loss) of mustard-mungbean-T. aman rice cropping system

\begin{tabular}{|c|c|c|c|c|c|c|}
\hline Treatment & $\mathrm{N}$ & $\mathrm{P}$ & $\mathrm{K}$ & S & $\mathrm{Zn}$ & $\mathrm{B}$ \\
\hline Nutrients input & \multicolumn{6}{|c|}{ - } \\
\hline Control $\left(\mathrm{T}_{1}\right)$ & 0.00 & 0.55 & 5.98 & 3.26 & 0.076 & 0.34 \\
\hline F. practice $\left(\mathrm{T}_{2}\right)$ & 183 & 43.6 & 44.0 & 3.26 & 0.076 & 0.34 \\
\hline $\operatorname{AEZ}\left(\mathrm{T}_{3}\right)$ & 141 & 36.6 & 43.0 & 28.3 & 2.08 & 0.84 \\
\hline $\operatorname{STB}\left(\mathrm{T}_{4}\right)$ & 241 & 60.6 & 172 & 47.3 & 5.58 & 5.34 \\
\hline \multicolumn{7}{|l|}{ Nutrient output } \\
\hline Control $\left(\mathrm{T}_{1}\right)$ & 162 & 18 & 153 & 18.8 & 0.49 & 0.32 \\
\hline F. practice $\left(\mathrm{T}_{2}\right)$ & 212 & 23 & 195 & 27.3 & 0.59 & 0.38 \\
\hline $\operatorname{AEZ}\left(\mathrm{T}_{3}\right)$ & 248 & 28 & 224 & 32.8 & 0.75 & 0.62 \\
\hline $\operatorname{STB}\left(\mathrm{T}_{4}\right)$ & 296 & 33 & 258 & 39.7 & 0.86 & 0.73 \\
\hline
\end{tabular}

\subsection{Apparent Nutrients Balance}

Calculation of apparent nutrient balance was made allowing the amount of added nutrient through fertilizer, rain, irrigation water minus the amount of nutrient removed by crops and leaching loss. However, the nutrient balance did not account for the addition of $\mathrm{N}$ from rainfall, irrigation water, or gaseous losses or BNF. Apparent balance of N, P, K, S, Zn and B are shown in Figures 4 and 5. Different nutrient management practices contributed to change (positive or negative) the apparent nutrient balance in soil.

Results revealed that, $\mathrm{N}$ balance was negative in all the treatment and the depletion ranged from -29.0 to $-162 \mathrm{~kg}$ $\mathrm{N} \mathrm{ha}^{-1} \mathrm{yr}^{-1}$. In case of $\mathrm{P}$ balance, the values was negative $\left(-17.5 \mathrm{~kg} \mathrm{ha}^{-1} \mathrm{yr}^{-1}\right)$ in control treatment $\left(\mathrm{T}_{1}\right)$ and positive ( 8.60 to $27.6 \mathrm{~kg} \mathrm{ha}^{-1} \mathrm{yr}^{-1}$ ) in all other treatment where the $\mathrm{P}$ magnitude was greater in soil receiving from fertilizer. The soils of all treatments were showed negative $\mathrm{K}$ balance where the $\mathrm{K}$ mining ranged from -86.0 to $-181 \mathrm{~kg} \mathrm{~K} \mathrm{ha}{ }^{-1} \mathrm{yr}^{-1}$. The greatest K mining was measured from AEZ based nutrient management practice $\left(\mathrm{T}_{3}\right)$ followed by farmer practice $\left(T_{2}\right)$ and the lowest K mining was calculated in STB nutrient treatment $\left(T_{4}\right)$.

Among the treatments, the balance for $\mathrm{S}$ was showed negative value in control, farmers practice and AEZ based nutrient treatments $\left(\mathrm{T}_{3}\right)$ varied from -4.50 to $-24.0 \mathrm{~kg} \mathrm{ha}^{-1} \mathrm{yr}^{-1}$ although $\mathrm{T}_{4}$ treatment observed positive $(7.60 \mathrm{~kg}$ $\left.\mathrm{ha}^{-1} \mathrm{yr}^{-1}\right)$. Regarding micronutrients, $\mathrm{Zn}$ balance was observed negative in control and farmers practice ranged from -0.41 to $-0.51 \mathrm{~kg} \mathrm{ha}^{-1} \mathrm{yr}^{-1}$, respectively. Remaining treatments contributed to obtain positive $\mathrm{Zn}$ balance ranged from 1.33 to $4.72 \mathrm{~kg} \mathrm{ha}^{-1} \mathrm{yr}^{-1}$. The negative $\mathrm{B}$ balance $\left(-0.04 \mathrm{~kg} \mathrm{ha}^{-1} \mathrm{yr}^{-1}\right)$ was found only in farmers practice $\left(T_{2}\right)$. The other treatments showed positive $B$ balance ranged from 0.02 to $4.61 \mathrm{~kg} \mathrm{ha}^{-1} \mathrm{yr}^{-1}$, respectively. The highest positive balance of Zn $\left(4.72 \mathrm{~kg} \mathrm{ha}^{-1} \mathrm{yr}^{-1}\right)$ and B $\left(4.61 \mathrm{~kg} \mathrm{ha}^{-1} \mathrm{yr}^{-1}\right)$ was estimated from STB $\left(\mathrm{T}_{4}\right)$ treatment. 
$\square$ Control (T1) $\quad$ m. practice (T2) $\quad$ AEZ (T3) $\square \mathrm{STB}(\mathrm{T} 4)$

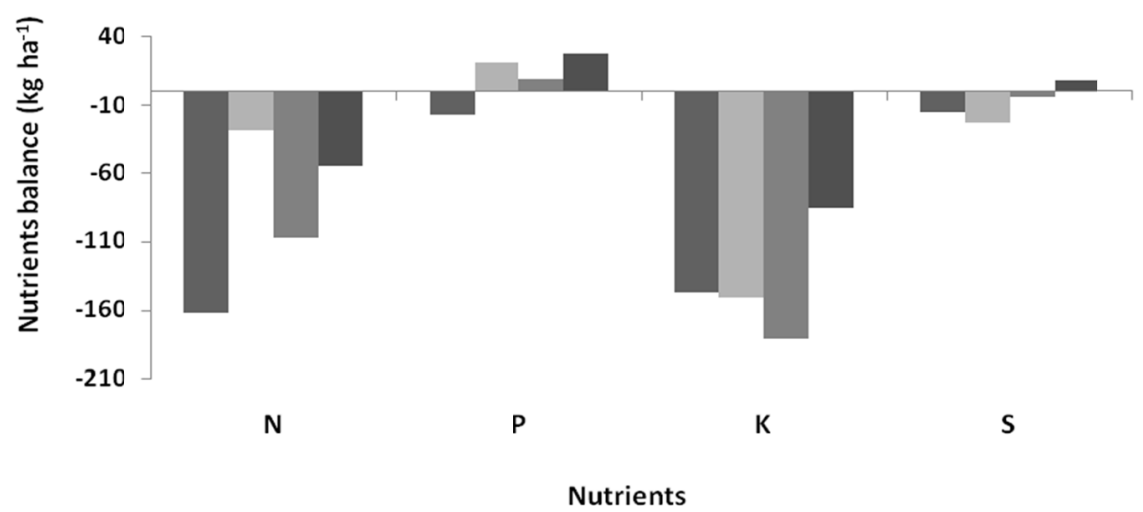

Figure 4. Effect of nutrient management practices on apparent nutrient balance of N, P, K and S in soil under mustard-mungbean- $\mathrm{T}$. aman rice cropping system

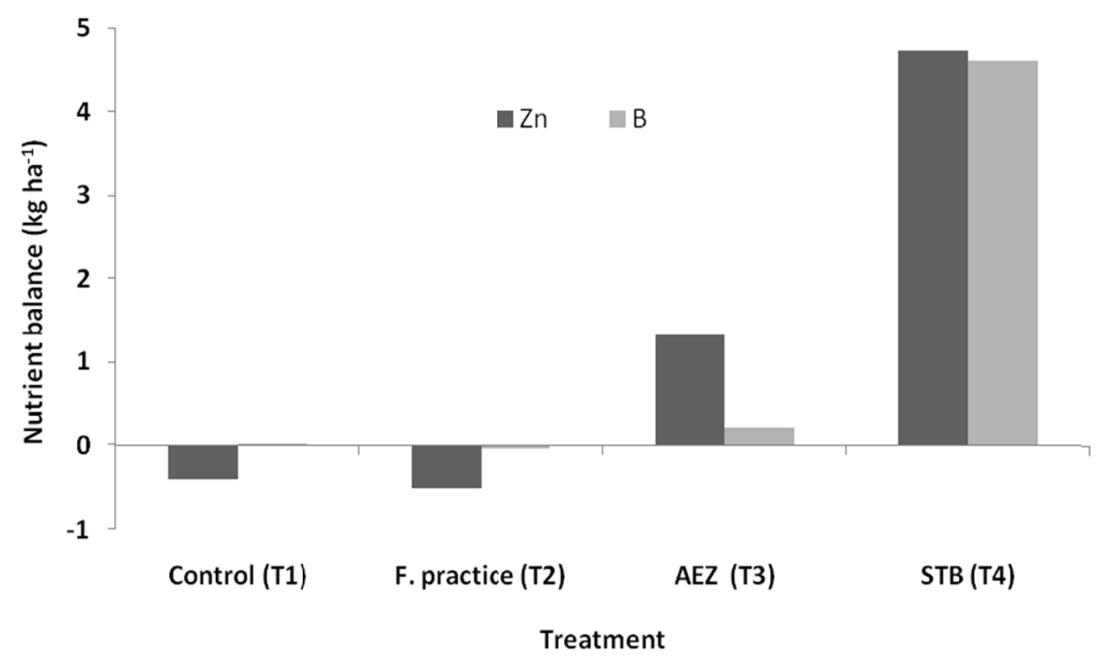

Figure 5. Effect of nutrient management practices on apparent balance of zinc and boron in soil under mustard-mungbean-T. aman rice cropping system

\subsection{Soil Fertility}

Post harvest soil samples $(0-15 \mathrm{~cm}$ depth) were collected from each treated plot after two cycles of mustard-mungbean-T. aman rice cropping system for analyzing different soil properties viz. soil $\mathrm{pH}$, organic matter, total $\mathrm{N}$ and available $\mathrm{P}, \mathrm{K}, \mathrm{S}, \mathrm{Zn}$ and $\mathrm{B}$. The initial and post harvest soil data are presented in Table 9. Initially the soil $\mathrm{pH}$ was 7.3 , but after completion of two crop cycles and incorporation of mungbean stover and other crop residues in soil, the $\mathrm{pH}$ remained static while minor variation existed in different nutrient treatments. After two years, the status of soil fertility demonstrated minor change from initial status due to different nutrient management practices. Soil test based nutrient application $\left(\mathrm{T}_{4}\right)$ biased to maintain the initial fertility or increased the soil fertility slightly (Table 9). The treatment $T_{4}$ and $T_{3}$ both were showed a positive effect on organic matter, $\mathrm{N}, \mathrm{P}, \mathrm{S}, \mathrm{Zn}$ and $\mathrm{B}$. Among the treatment, the $\mathrm{T}_{4}$ maintained the highest fertility viz. organic matter, $\mathrm{N}, \mathrm{P}, \mathrm{S}, \mathrm{Zn}$ and $\mathrm{B}$ status in soil. In case of $\mathrm{K}$ which was slightly decreased in all plots over the initial status. The available $\mathrm{Zn}$ and $B$ content of the soil slightly decreased when they were not applied $\left(T_{1}\right.$ and $\left.T_{2}\right)$, but remained almost static or increase when applied (Table 9). 
Table 9. Effect of different nutrient management practices on soil fertility

\begin{tabular}{|c|c|c|c|c|c|c|c|c|}
\hline Treatment & $\mathrm{pH}$ & $\mathrm{OM}$ & Total $\mathrm{N}$ & $\mathrm{K}$ & $\mathrm{P}$ & $\mathrm{S}$ & $\mathrm{Zn}$ & $\mathrm{B}$ \\
\hline & & \multicolumn{2}{|c|}{------------- \% ------------- } & -- meq. $100 \mathrm{~g}^{-1}--$ & \multicolumn{4}{|c|}{---------------------- $\mu \mathrm{g} \mathrm{g}^{-1}$-------------------- } \\
\hline Initial & 7.3 & 1.41 & 0.062 & 0.16 & 14.0 & 17.0 & 1.20 & 0.14 \\
\hline Control $\left(\mathrm{T}_{1}\right)$ & 7.4 & 1.41 & 0.062 & 0.13 & 13.8 & 16.5 & 1.17 & 0.12 \\
\hline F. practice $\left(\mathrm{T}_{2}\right)$ & 7.3 & 1.44 & 0.064 & 0.14 & 14.8 & 17.8 & 1.18 & 0.12 \\
\hline $\operatorname{AEZ}\left(\mathrm{T}_{3}\right)$ & 7.3 & 1.45 & 0.065 & 0.14 & 15.0 & 18.0 & 1.24 & 0.14 \\
\hline $\mathrm{STB}\left(\mathrm{T}_{4}\right)$ & 7.2 & 1.50 & 0.067 & 0.15 & 15.3 & 18.3 & 1.30 & 0.17 \\
\hline
\end{tabular}

\subsection{Economic Analysis}

Different nutrient management practices contributed directly to change the gross return of mustard-mungbean-T. aman rice cropping system. Gross returns depended to the market price that received from the product. Results revealed that the gross return was calculated highest (Tk. $243458 \mathrm{ha}^{-1} \mathrm{yr}^{-1}$ ) in the treatment $\mathrm{T}_{4}$ followed by $\mathrm{T}_{3}$ \& $\mathrm{T}_{2}$ and the lowest was in control treatment. The maximum gross margin was recorded from $\mathrm{T}_{4}$ and second from $\mathrm{T}_{3}$ treatment over control $\left(\mathrm{T}_{1}\right)$. The highest marginal benefit cost ratio (5.05) was recorded in $\mathrm{T}_{3}$ followed by $\mathrm{T}_{4}$. In this study $\mathrm{T}_{3}$ was economically viable due to the cost of production of $\mathrm{T}_{3}\left(\mathrm{Tk} .68608 \mathrm{ha}^{-1} \mathrm{yr}^{-1}\right)$ was lower than $\mathrm{T}_{4}$ (Tk. $\left.86138 \mathrm{ha}^{-1} \mathrm{yr}^{-1}\right)($ Table 10).

Table 10. Economic analysis of mustard-mungbean-T. aman rice cropping system affected by different nutrient management practices

\begin{tabular}{|c|c|c|c|c|c|c|}
\hline Treatment & Variable cost & Gross return & $\begin{array}{l}\text { Added cost } \\
\text { over control }\end{array}$ & $\begin{array}{l}\text { Added benefit } \\
\text { over control }\end{array}$ & $\begin{array}{l}\text { Gross margin } \\
\text { over control }\end{array}$ & MBCR \\
\hline & \multicolumn{6}{|c|}{ 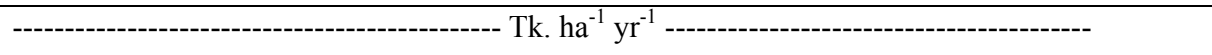 } \\
\hline Control $\left(\mathrm{T}_{1}\right)$ & 56110 & 148067 & - & - & - & - \\
\hline F. practice $\left(\mathrm{T}_{2}\right)$ & 67999 & 184492 & 11889 & 36425 & 25123 & 3.06 \\
\hline $\operatorname{AEZ}\left(\mathrm{T}_{3}\right)$ & 68608 & 211223 & 12498 & 63156 & 50658 & 5.05 \\
\hline $\operatorname{STB}\left(\mathrm{T}_{4}\right)$ & 86138 & 243458 & 30028 & 95391 & 63363 & 3.18 \\
\hline
\end{tabular}

Note. Input prices: Urea $=$ Tk.12 $\mathrm{kg}^{-1}$, T.S.P. $=$ Tk.22 kg ${ }^{-1}, \mathrm{MoP}=\mathrm{Tk} .20 \mathrm{~kg}^{-1}, \mathrm{Gypsum}=\mathrm{Tk} .6 \mathrm{~kg}^{-1}$, Zinc sulphate $=$ Tk.120 kg $\mathrm{kg}^{-1}$, Boric acid $=\mathrm{Tk} .300 \mathrm{~kg}^{-1}$, Rovral fungicide $=\mathrm{Tk} .250100 \mathrm{~g}^{-1}$, Bavistin fungicide $=$ Tk.200 $100 \mathrm{~g}^{-1}$, Provex fungicide $=T k .3200 \mathrm{~kg}^{-1}$, Ripcord insecticide $=$ Tk.105 $100 \mathrm{~g} \mathrm{~g}^{-1}$, Karate insecticide $=$ Tk.450 $500 \mathrm{ml}^{-1}$, Plowing $=$ Tk.1400 ha ${ }^{-1}$ (one pass), Labour wage $=$ Tk.125 day ${ }^{-1}$, Mustard seed $=\mathrm{Tk} .45 \mathrm{~kg}^{-1}$, Mungbean seed $=$ Tk. $60 \mathrm{~kg}^{-1}, \mathrm{~T}$. aman rice seed $=$ Tk. $35 \mathrm{~kg}^{-1}$.

Output prices: Mustard grain $=$ Tk. $35 \mathrm{~kg}^{-1}$, Mungbean grain $=T \mathrm{k} .55 \mathrm{~kg}^{-1}$, T. aman rice grain $=\mathrm{Tk} .19 \mathrm{~kg}^{-1}$, Mustard straw rate $=$ Tk.1 $\mathrm{kg}^{-1}$, Rice straw $=$ Tk. $1.25 \mathrm{~kg}^{-1}$.

\section{Discussion}

Crops need timely balanced nutrient for good growth and high yields. As we compared some selected nutrient management practices by considering mustard-mungbean- $T$. aman rice cropping system in calcareoues soil. Nutrient management practices contributed significantly to achieve positive yields of mustard, mungbean and T. aman rice. Among the nutrient management practices, we observed that the greatest yields of mustard obtained from soil test based nutrient management practices $\left(T_{4}\right)$. Shahiduzzaman and Rahman (2008) also observed that soil test based fertilizer treatment produced the highest yield of mustard. Quddus et al. (2017) reported in another paper that the highest grain yield of mustard $\left(1543 \mathrm{~kg} \mathrm{ha}^{-1}\right)$ got from soil test basis fertilizer application. Similar yield trend was found in grain yield of mungbean. This result is in agreement with findings of Haque et al. (2011) that the combined effect of fertilizer gave the higher yield of mungbean over the native nutrient treatment. Singh et al. (2014) reported that recommended balance fertilization led to a better grain yield of mungbean. The third crop rice also yielded higher from the soil test based nutrient management practice $\left(\mathrm{T}_{4}\right)$. Timsina et al. (2006) supported the rice yield result that the highest grain yields with STB nutrient in T. aman rice on rice-wheat system. Similar results are also reported by many of researchers (Quayyum et al., 2001; Basak et al., 2008; Ali et al., 2009; Gupta \& Mehta, 1993). 
The yields of mustard, mungbean and T. aman rice in second year of this study were relatively higher in $\mathrm{T}_{3}$ and $\mathrm{T}_{4}$ treatments than that of first year. The fertility status of initial soil was very low to low. After two crop cycles, the soil fertility status showed an increasing trend while minor exception existed. Incorporation of mungbean biomass and rice residues in soil might be improved fertility which increased the crop yields in second year.With the inclusion of legumes in cropping system, the crop residues left back in the field contain nutrients especially nitrogen (Kumar \& Singh, 2009; Nawab et al., 2011; Aggarwal et al., 1997).

Comparisions the grain nutrient concentrations measured in these studies with critical limits collected from different published articles (Kalra, 1998; Bell \& Kovar, 2000; Grain Legume Handbook, 2017; Plant Analysis Handbook, 2017). Results revealed that, N, K and Zn deficiency detect clear in mustard, mungbean and $\mathrm{T}$. aman rice for all nutrient management treatment. Nitrogen and $\mathrm{K}$ deficiency detected more in $\mathrm{T}$. aman rice and $\mathrm{K}$ deficiency also detection distinct in mustard crop. In case of nutrient concentration among the treatments, higher concentration of $\mathrm{N}, \mathrm{K}$ and $\mathrm{Zn}$ showed in $\mathrm{T}_{4}$ and lower concentrations in control treatment. This variation might be due to rate of nutrient application in soil. On the other hand, N, K and Zn deficiency occurred in all test crops in all the treatments. This study indicated that the test crops might be affected the unavailability of applied nutrient in soil caused as chemical fixation or leaching loss or inadequate moisture in root zone. Similar research has shown by Timsina et al. (2006) and Panaullah et al. (2006). In case of P showed slightly deficient in T. aman rice in all treatment but slightly sufficient in mustard and mungbean for all the treatment except mungbean in control treatment. Phosphorus deficiency occurred in T. aman rice in all treatments but no deficiency in other two crops. Phosphorus deficiency for T. aman rice in calcareous soil might be formed Ca-phosphate compounds which decreased the solubility of P (Kirk et al., 1990). Also probably the soils of this study has not increased plant-available P. Sulphur deficiency detect in mungbean and T. aman rice but S sufficiency only in mustard. T. aman rice maintained adequate levels of $\mathrm{B}$ in grain but deficiency of $\mathrm{B}$ detect in mustard and mungbean for all the treatment. The results are in agreement with the observation of Bell and Kovar (2000) and Kalra (1998).

The present study demonstrated that the different nutrient management practices influenced significantly to uptakes of N, P, K, S, Zn and B by the system crops. In this research, the cronological nutrient uptake increase of crops from treatments $T_{1}$ to $T_{4}$ that indicated the soils were defficient in nutrients and the fertilizer doses under $\mathrm{T}_{4}$ were more balanced for all test crops to get higher yield. This indication supported by Vinay et al. (2007); Yamakawa et al. (2004); Islam (2003). In our study, a large amount of $\mathrm{N}$ uptake was observed in STB (296 kg $\left.\mathrm{ha}^{-1} \mathrm{yr}^{-1}\right)$ followed by AEZ $\left(\mathrm{T}_{3}\right)$ and minimum was in control $\left(\mathrm{T}_{1}\right)$. This finding is supported by Timsina et al. (2006) who reported that $\mathrm{N}$ uptake was consistently and significantly greater due to STB fertilizer management. The uppermost phosphorus uptake $\left(32.1 \mathrm{~kg} \mathrm{ha}^{-1} \mathrm{yr}^{-1}\right)$ was made from STB treatment and second from AEZ $\left(27.5 \mathrm{~kg} \mathrm{ha}^{-1} \mathrm{yr}^{-1}\right)$. The lowest uptake was made from control $\left(16.8 \mathrm{~kg} \mathrm{ha}^{-1} \mathrm{yr}^{-1}\right)$. The result is in agreement to the findings of M. Prasad and R. Prasad (1983) that about $35 \mathrm{~kg} \mathrm{P} \mathrm{ha}^{-1} \mathrm{yr}^{-1}$ uptake through rice-wheat cropping system in India. Shrestha and Ladha (2001) also observed that P uptake were 27, 42, 38 and $48 \mathrm{~kg} \mathrm{ha}^{-1} \mathrm{yr}^{-1}$ for sweet pepper-fallow-rice, sweet pepper-indigo-rice, sweet pepper-indigo + mungbean-rice and sweet pepper-corn-rice, respectively. In our study, increasing rate of $\mathrm{K}$ application through STB contributed great $\mathrm{K}$ uptake (248 $\left.\mathrm{kg} \mathrm{ha}^{-1} \mathrm{yr}^{-1}\right)$. Similarly Zhang et al. (2010) corroborated that balanced fertilization contributed to highest uptake of $\mathrm{K}$ ( $\left.309 \mathrm{~kg} \mathrm{ha}^{-1} \mathrm{yr}^{-1}\right)$ in rice-wheat cropping systems of southern China. Panaullah et al. (2006) reported greater $\mathrm{K}$ uptake $\left(239 \mathrm{~kg} \mathrm{ha}^{-1}\right)$ for rice-wheat sequence at Ishwordi and it was $116 \mathrm{~kg} \mathrm{ha}^{-1}$ for Gazipur which was lower than that of our study. In this trial, among the treatments, maximum S uptake was observed in STB (36.2 kg ha $\left.\mathrm{yr}^{-1}\right)$ followed by AEZ (29.5 kg ha $\left.\mathrm{yr}^{-1}\right)$. Minimum uptake was found in control treatment $\left(17.3 \mathrm{~kg} \mathrm{ha}^{-1} \mathrm{yr}^{-1}\right)$. The result confirm by the three years study conducted on calcareous soil 22 to $55 \mathrm{~kg} \mathrm{~S} \mathrm{ha}^{-1}$ $\mathrm{yr}^{-1}$ uptake was found in wheat-mungbean-T. aman rice cropping pattern (Haque et al., 2001). Tarafder et al. (2008) found that the highest uptake of $\mathrm{S}\left(67 \mathrm{~kg} \mathrm{ha}^{-1} \mathrm{yr}^{-1)}\right.$ through balanced fertilization in potato-boro-T. aman rice cropping system. This study observed the different nutrient management practices showed positive role to uptake of $\mathrm{Zn}$ and B by the system crops. Maximum $\mathrm{Zn}$ and B uptake $\left(0.74 \mathrm{~kg} \mathrm{Zn} \mathrm{ha}^{-1} \mathrm{yr}^{-1}\right.$ and $\left.0.44 \mathrm{~kg} \mathrm{~B} \mathrm{ha}^{-1} \mathrm{yr}^{-1}\right)$ was found in STB treatment and lowest in control. Similar observation was made by Paramasivan et al. (2012) who found $1.4 \mathrm{~kg} \mathrm{Zn} \mathrm{ha}{ }^{-1}$ was uptake in a maize cultivation. Maximum total $\mathrm{Zn}$ uptake $\left(1.31 \mathrm{~kg} \mathrm{ha}^{-1}\right)$ by three crops (maize-mungbean-rice cropping system) per year (Hossain et al., 2008). The B uptake confirmed by Verma et al. (2012) who reported that B uptake ranged from 0.113 to $0.160 \mathrm{~kg} \mathrm{ha}^{-1}$ by mustard. Jahan et al. (2015a) reported that in single cropping rice cultivation uptake of B was $0.27 \mathrm{~kg} \mathrm{ha}^{-1}$ in STB treatment and it was $0.04 \mathrm{~kg}$ $\mathrm{ha}^{-1}$ in control treatment.

In this system, different nutrient management practices contributed positively to change the apparent balance of N, P, K, S, Zn and B. The annual nutrients input aggregated from fertilizer, rainfall and irrigation water. The annual nutrient output estimated from crops uptake and leaching loss of nutrients. Balance calculation exhibited 
that removal of $\mathrm{N}$ and $\mathrm{K}$ exceeded input for all treatments but $\mathrm{P}, \mathrm{S}, \mathrm{Zn}$ and $\mathrm{B}$ was not exceeded the input for $\mathrm{T}_{3}$ and $\mathrm{T}_{4}$ treatment (Table 8).

Nutrient balance due to different nutrient management practices revealed that higher $\mathrm{N}$ mining $\left(-162 \mathrm{~kg} \mathrm{~N}^{-1}\right.$ $\left.\mathrm{yr}^{-1}\right)$ was observed in control plot as no fertilizers were used and less mining was found in farmer practice $\left(\mathrm{T}_{2}\right)$ and STB based nutrient treated plot. Farmers of Bangladesh are generally used more $\mathrm{N}$ through fertilizer in soil as a consequence, least $\mathrm{N}$ mining occurred in $\mathrm{T}_{2}$ treatment. Secondly lesser mining of $\mathrm{N}$ was occured in STB which might be added fertilizer including mungbean biomass and other crop residues to soil. Similarly Kumar and Goh (2000) also found minimum N mining from balanced fertilization. On the other hand, in this study apparent balance of $\mathrm{N}$ was negative in all the treatment and the depletion ranged from -29.0 to $-162 \mathrm{~kg} \mathrm{~N} \mathrm{ha}^{-1} \mathrm{yr}^{-1}$. The result is comparable with potato-boro-T. aman rice systems, the apparent $\mathrm{N}$ balance showed negative (-72.9 to $-177 \mathrm{~kg} \mathrm{ha}^{-1} \mathrm{yr}^{-1}$ ) (Ali et al., 2009b).

Phosphorus balance was highly positive due to soil test based nutrient treatment $\left(\mathrm{T}_{4}\right)$ than the other treatments while control treatment was negative no P containing fertilizer used. According to the above statement the soils were over fertilized with respect to $P$, but considerable amount of added $P$ became unavailable (due to chemical fixation, or inadequate moisture in the fertilizer zone) in this soil especially for dry land crops. Saleque et al. (2006) also expressed the same opinion after conducting experiment in calcareous soils of Ishurdi, Bangladesh. In another study, rice-maize system in Bangladesh, the apparent $\mathrm{P}$ balance was found positive (15 to $33 \mathrm{~kg} \mathrm{ha}^{-1}$ ) (Ali et al., 2009).

The K balance was highly negative in all the treatment under this system. The negative balance of $\mathrm{K}$ was the combined effort of uptake by crops and leaching loss, both of which was increased with increasing input of K. The input of $\mathrm{K}$ varied from 44 to $172 \mathrm{~kg} \mathrm{ha}^{-1}$. But the nutrient output was extremely high ranging from 195 to $257 \mathrm{~kg} \mathrm{~K} \mathrm{ha}^{-1}$. The amount of K added for mustard through the treatment $\mathrm{T}_{4}$ was sufficiant for sustaining $\mathrm{K}$ fertility but the amount added for mungbean $\left(8\right.$ to $\left.30 \mathrm{~kg} \mathrm{ha}^{-1}\right)$ and $\mathrm{T}$. aman $\left(12\right.$ to $\left.66 \mathrm{~kg} \mathrm{ha}^{-1}\right)$ was very low compared to uptake (62 to $63 \mathrm{~kg} \mathrm{ha}^{-1}$ by mungbean and 76.6 to $108 \mathrm{~kg} \mathrm{ha}^{-1}$ by T. aman). This below fertilization of $\mathrm{K}$ in mungbean and $\mathrm{T}$. aman rice was mainly responsible for negative balance of $\mathrm{K}$. Balanced fertilization contributed the lesser depletion of K from soil. Similar results was also observed by Sharif (2009); Regmi et al. (2002); Bijay and Yadvinder (2002). The depletion ranged of $\mathrm{K}$ from -86.0 to $-181 \mathrm{~kg} \mathrm{ha}^{-1}$. The results confirmed the declining trends in available soil $\mathrm{K}$ in many treatments and they are comparable with many other long-term studies in rice-rice and rice-wheat systems of Asia (Ladha et al., 2003). Biswas et al. (2006) found that the apparent average annual $\mathrm{K}$ balances were all negative and ranged from $-179 \mathrm{~kg} \mathrm{ha}^{-1} \mathrm{yr}^{-1}$ in jute-rice-rice to $-39 \mathrm{~kg}$ $\mathrm{ha}^{-1}$ in rice-potato-sesame.

The farmers of the studied areas do not use $\mathrm{S}$ in dry land crops even in $\mathrm{T}$. aman rice. The amount added to the soils through rainfall and irrigation was quite insufficiant for the crops of this system. As a results, minining of native $S$ showed in treatment $T_{1}$ (control) and $T_{2}$ (farmers practice). The amount of $S$ added through $T_{3}$ and $T_{4}$ to mungbean and $\mathrm{T}$. aman rice was nearly sufficiant to fulfil the requirement of crops. But mustard was below fertilized with respect to $\mathrm{S}$ which brought about a mild negative balance in $\mathrm{T}_{2}$ (farmers practice) treatment. However, the soil test based fertilization $\left(\mathrm{T}_{4}\right)$ was almost balanced for this system. The STB $\left(\mathrm{T}_{4}\right)$ treatment seemed to contribute $\mathrm{S}$ build up in soil but low $\mathrm{S}$ detection in mungbean and $\mathrm{T}$. aman rice which suggest an increased dosage of S fertilizer. Similar observation prepared by Yoshida (1981) and Reuter et al. (1997).

The balance for $\mathrm{Zn}$ was negative in $\mathrm{T}_{1}$ (control) and $\mathrm{T}_{2}$ (farmers practice) treatments because no $\mathrm{Zn}$ and $\mathrm{B}$ fertilizers were applied. The output of $\mathrm{Zn}$ under AEZ based recommended nutrient treatment $\left(\mathrm{T}_{3}\right)$ and soil test based nutrient treatment $\left(\mathrm{T}_{4}\right)$ was nearly $1 \mathrm{~kg}$ or less, but total addition was 4-5 times higher. So, the AEZ $\left(\mathrm{T}_{3}\right)$ and soil test based treatments $\left(\mathrm{T}_{4}\right)$ showed positive balance of $\mathrm{Zn}$. Similar results corroborated by Jahan et al. (2015b) in a monocrop cultivation of T. aman rice where -0.08 to $-0.31 \mathrm{~kg} \mathrm{Zn} \mathrm{ha}^{-1} \mathrm{yr}^{-1}$ was in control and farmers practice and positive balance (1.12 to $1.61 \mathrm{~kg} \mathrm{Zn} \mathrm{ha}^{-1} \mathrm{yr}^{-1}$ ) was in AEZ and STB treatment. Deficiency detection of $\mathrm{Zn}$ in mustard, mungbean and $\mathrm{T}$. aman rice in all treatments suggested for application of $\mathrm{Zn}$ fertilizer or further monitoring (Bell \& Kovar, 2000; Kalra, 1998). The apparent balance for B was negative in farmers practice and almost static in control due to no B fertilizer was used, but in AEZ $\left(T_{3}\right)$ and soil test based treatments $\left(T_{4}\right)$ the balance was positive because of $B$ fertilization. Other study has also showed positive balance of B in maize-mungbean-rice system when this was added (Hossain et al., 2008). In this study deficiency detection of $\mathrm{B}$ in mustard and mungbean grain and sufficiency detection in rice grain. Results suggests for suitable dose of B fertilization. Some researchers concluded excess B supply may influence as inhibitor and balanced B supply may influence as regulator (Tanada, 1983; Alvarez-Tinant et al., 1979; Corey \& Schulte, 1973). 
Economic analysis indicated that the gross return and gross margin over control by $\mathrm{T}_{4}$ was highest over other treatment but considering the marginal benefit cost ratio (MBCR) $T_{3}$ treatment showed ranked first and second in $\mathrm{T}_{4}$. In this system the fertilizer dose under $\mathrm{T}_{3}$ were found low however, the cost of production of $\mathrm{T}_{3}(\mathrm{Tk} .68608$ $\mathrm{ha}^{-1} \mathrm{yr}^{-1}$ ) was lower than $\mathrm{T}_{4}\left(\mathrm{Tk} .86138 \mathrm{ha}^{-1} \mathrm{yr}^{-1}\right)$ (Table 10). Therefore, the gross return, gross margin and soil fertility indicate the treatment $T_{4}$ is preferable to $T_{3}$. Similar results corroborated by Quddus et al. (2017) in other paper that the highest marginal benefit-cost ratio of 3.46 in $\mathrm{T}_{3}$ (AEZ) and second in $\mathrm{T}_{4}$ (STB). In contrast Ali et al. (2003) and Rahman et al. (2004) who observed in cropping system that highest benefit cost ratio got from the soil test based balanced fertilization.

The above discussions suggest that soil test based of nutrients (N, P, K, S, Zn and B) recommendation need to be monitored for obtaining higher productivity.

\section{Conclusion}

From our study it is clear that nutrient additions through soil test based practice contributed to achieve higher crops yield of the system. The nutrient uptake by mustard, mungbean and T. aman rice were also observed to be higher in soil test based treatment. The calculated apparent nutrient balance, which is an account of inputs (fertilizer, nutrient got from rain and irrigation water) and outputs (crop uptake and leaching loss), might be used as a tool to develop suitable nutrient management that will help for deciding fertilizer application dose in farmers field. Whereas apparent nutrients balance at the end of the cycle showed dissimilar results due to different nutrient management practices depending on the nutrients. Most of the treatments showed greater negative balance of $\mathrm{N}$ and $\mathrm{K}$ nutrient than the other nutrients ( $\mathrm{P}, \mathrm{S}, \mathrm{Zn}$ and $\mathrm{B}$ ). Nitrogen and $\mathrm{K}$ mining happened remarkably from the soil. So, the rates of application of these two nutrients should be increased. Regarding the gross return, gross margin over control and soil fertility the soil test based nutrient management practice (STB) is economically lucrative and practical for achieving sustainable crop yields in calcareous soils of Bangladesh. On the basis of marginal benefit cost ratio low income farmers may be recommended the AEZ based nutrient management practice although it gives low yield and declines soil fertility. Based on the present study it is an utmost necessary to have clear concept about nutrient dynamics for different cropping sustem in different AEZ of Bangladesh should be carried out.

\section{Acknowledgements}

The first author gratefully acknowledges the Ministry of Science and Technology, Bangladesh, for offering scholarship and financial support to carry out the study. Thanks to the Chief Scientific Officer, Soil Science Division, Bangladesh Agricultural Research Institute, Gazipur, Bangladesh for arranging laboratory facilities for execution of different analysis.

\section{References}

Abedin, M. J., Blume, H. P., Bhuiyan, Z. H., \& Eaqub, M. (1991). Water and Nutrient dynamics of a paddy soil in Bangladesh. Pflanzenernaehr Bodenkd, 154, 93-99. https://doi.org/10.1002/jpln.19911540204

Aggarwal, P., Parashar, D. K., Kumar, V., \& Gupta, R. P. (1997). Effect of kharif green manuring and rabi tillage on physical properties of clay loam under rice-wheat rotation. J Indian Society of Soil Science, 45(3), 434-438.

Ali, M. M., Shaheed, S. M., Kabuta, D., \& Wakatsuki, T. (1997). Soil degredation during the period 1967-1995 in Bangladesh. II. Selected chemical characters. Soil Science and Plant Nutrient, 43, 870-890. https://doi.org/10.1080/00380768.1997.10414654

Ali, M. R., Costa, D. J., Sayed, M. A., Khan, M. A. H., \& Abedin, J. A. (2009b). Development of fertilizer recommendation for the cropping pattern potato-boro-T. aman in irrigated medium highland condition under AEZ-9. Bangladesh J. Agril. Res., 34(1), 41-49. https://doi.org/10.3329/bjar.v34i1.5751

Ali, M. R., Rahman, M. S., Mannan, M. A., Hossain, M. M., \& Kader, M. (2003). Balanced fertilization with inorganic fertilizers in Mustard-Boro-T. aman cropping pattern. Bangladesh Journal of Progressive Science \& Technology, 1(1), 33-37.

Ali, M. R., Rahman, M. S., Mannan, M. A., Hossain, M. M., \& Kadir, M. (2009). Balanced fertilization with inorganic fertilizers in Mustard-Boro-T. aman cropping pattern. Bangladesh J Prog Sci Tech, 1(1), 33-37.

Alvarez-Tinant, Mc., Leal, A., Agui, I., \& Recalde-Martinez, L. (1979). Physiological effects of B-Mn interaction in tomato plants III. The uptake and translocation of microelements. Analse de Edafologiay Agrobiologia, 38, 1013-1029. 
Andreae, M. O., Talbot, R. W., Berresheim, H., \& Beecher, K. M. (1990). Precipitation chemistry in central Amazonia. Journal of Geophysics Research, 95(D10), 16987-16999. https://oi.org/10.1029/JD095iD $10 \mathrm{p} 16987$

Basak, N. C., Quayyum, M. A., Asaduzzaman, S. M., Sultana, N., \& Khan, M. A. H. (2008). Integrated nutrient management in the Mustard-Boro rice-T. aman rice cropping system. Bangladesh J. Agril. Res., 33(1), 135-143.

BBS (Bangladesh Bureau of Statistics). (2012). Statistical Yearbook of Bangladesh. Bangladesh Bureau of Statistics, Ministry of Planning, Dhaka, Bangladesh.

Bell, P. F., \& Kovar, J. L. (2000). Reference sufficiency ranges for plant analysis in the southern region of the United States. In C. R. Campbell (Ed.), Southern Cooperative Series Bulletin (p. 394).

Bijay, S., \& Yadvinder, S. (2002). Potassium nutrition of Rice-Wheat cropping system. Department of soil Science, Punjab Agricultural University, Ludhiana, India.

Bindraban, P. S., Stoorvogel, J. J., Jansen, D. M., Vlaming, J., \& Groot, J. J. R. (2000). Land quality indicators for sustainable land management: Proposed method for yield gap and soil nutrient balance. Agric. Ecosyst. Environ., 81, 103-112. https://doi.org/10.1016/S0167-8809(00)00184-5

Biswas, B., Ghosh, D. C., Dasgupta, M. K., Trivedi, N., Timsina, J., \& Dobermann, A. (2006). Integrated assessment of cropping systems in the Eastern Indo-Gangetic plain. Field Crops Res, 99, 35-47. https://doi.org/10.1016/j.fcr.2006.03.002

Biswas, J. C., Saleque, M. A., Moniruzzaman, M., \& Sattar, M. A. (2003). Soil test based fertilizer management for rice production at farmer's field. Proceeding of First Annual Workshop of ICM Sub-Project In Northern Region of Bangladesh, January 5, 2003 (pp. 25-30).

Blaise, D., Singh, J. V., Bonde, A. N., Tekale, K. U., \& Mayee, C. D. (2005). Effects of farmyard manure and fertilizers on yield, fibre quality and nutrient balance of rainfed cotton (Gossypium hirsutum). Bioresource Technology, 96, 345-349. https://doi.org/10.1016/j.biortech.2004.03.008

Bremner, J. M., \& Mulvaney, C. S. (1982). Total nitrogen. In A. L. Page, R. H. Miller, D. R. Keeney (Eds.), Methods of Soil Analysis (Part 2, 2nd ed., pp. 599-622). Am. Soc. Agron., Madison, USA.

Chitdeshwari, T., Velu, V., \& Thilagavathy, T. (2011). Nutrient balance studies in the soils under intensive rice-rice system. Indian J. Agric. Res., 45(1), 11-20.

Corey, R. B., \& Schulte, E. E. (1973). Factors affecting the availability of nutrients to plants. In L. M. Walsh, \& J. D. Beaton (Eds.), Soil Testing and Plant Analysis (pp. 23-34). Soil Sci. Soc. Am. Inc. Madison, Wisconsis, USA.

Filep, T. (2002). Characterization of the nutrient buffering capacity of $\mathrm{K}, \mathrm{Ca}, \mathrm{Mg}$ in two Hungarian soils. Agrokemia-es- Palajtan, 51, 73-78.

Fox, R. L., Olsen, R. A., \& Rhoades, H. F. (1964). Evaluating the sulphur status of soil by plant and soil test. Soil Science Society of America Proc, 28, 243-246. https://doi.org/10.2136/sssaj1964.03615995002800020034x

FRG, (2012). Fertilizer Recommendation Guide. Published by Bangladesh Agricultural Research Council, Dhaka, Bangladesh.

GIlles, B., Alain-Louis, D., Patrick, B., Rémi, L., \& Emmanouela, R. (1989). Seasonal variability of the elemental composition of atmospheric aerosol particles over the northwestern Mediterranean. Tellus B: Chemical and Physical Meteorology, 41(3), 353-361. https://doi.org/10.3402/tellusb.v41i3.15092

Gomez, K. A., \& Gomez, A. A. (1984). Statistical Procedures for Agricultural Research. International Rice Research Institute, John Wiley \& Sons, NY.

Grain Legume Handbook. (2017). Nutrition. Sponsored by Grain Research and Development Corporation (GRDC), Updated 1998.

Gupta, V. K., \& Mehla, D. S. (1993). Depletion of micronutrients from soil and their uptake in Rice-Wheat rotation. Journal of Indian Society of Soil Science, 41(4), 704-706.

Hanks, R. J., \& Ashcroft, G. L. (1980). Applied Soil Physics: Soil Water and Temperature Applications (pp. 1-159). Springer-Verlag Berlin, Heidelberg, Newyork. https://doi.org/10.1007/978-1-4684-0184-4 
Haque, M. A., Alam, M. J., Banu, M. B., \& Noor, S. (2011). Integrated nutrient management for sustaining soil fertility and production of Mustard-Mungbean-T. Aman cropping pattern. Annual Research Report 2010-2011. Soil Science Division, BARI, Gazipur.

Haque, M. Q., Rahman, M. H., Islam, F., Rijpma, J., \& Kadir, M. M. (2001). Integrated nutrient management in relation to soil fertility and yield sustainability under Wheat-Mungbean-T. aman cropping pattern. J. Biol. Sci., 1(8), 731-734. https://doi.org/10.3923/jbs.2001.731.734

Hasan, M. K., Hossain, M. A., Awal, M. A., \& Choudhury, D. A. (2003). Evaluation of fertilizer Application practices in major cropping systems under selected AEZ's of Bangladesh. Bangladesh J. Agric. Res., 28(4), 481-492.

Havlin, J. L., Beaton, J. D., Tisdale, S. L., \& Nelson, W. L. (1999). Soil Fertility and Fertilizers (6th ed., p. 499). Upper Saddle River, N.J. Prentice-Hall, Inc.

Hossain, M. A. (2007). Requirement of boron for Mustard-Mungbean-Rice pattern and zinc for Maize-Mungbean-Rice pattern in calcareous soil (pp. 1-2). Ph.D. Thesis, Department of Soil Science BAU, Mymensingh.

Hossain, M. A., Jahiruddin, M., Islam, M. R., \& Mian, M. H. (2008). The requirement of zinc for improvement of crop yield and mineral nutrition in the maize-mungbean-rice system. Plant and Soil, 306, 13-22. https://doi.org/10.1007/s11104-007-9529-5

Iqbal, T. M. T., Alam, M. S., \& Gaffar, M. A. (1990). Management of Agriculture Farm (2nd ed.). Published by S. Alam, 392, N Shahjahanpur, Dhaka.

Islam, I. M., Hossain, M. A., Mondol, M. A., Ahmed, S., Ahmad, K. U., \& Khatun, F. (2007). Soil Nutrient Management through Cultivation of Pulses-A system approaches. In M. A. Bakr, M. A. Afzal, \& H. U. Ahmed (Eds.), New Perspectives of Pulses Research in Bangladesh. Proceedings of the national workshop on "Pulses for Nutritional Security and Sustainable Agriculture". July 24-25, 2007, BARI, Joydebpur, Gazipur.

Islam, M. S. (1995). Integrated nutrientent management approach for fertilizer recommendation in cropping patterns under different soil conditions of Bangladesh. Proceeding of Intercongress Conference of Commission $I V$ (pp. 147-156). December 1-3, 1992, Dhaka, Bangladesh.

Islam, M. S. (2003). Impact of long-term application of organic matter on soil properties and crop production (Ph.D. Thesis. Department of Soil Science, BSMRAU, Gazipur).

Islam, M. S., Satter, M. A., \& Rahman, M. A. (2002). Integrated nutrient management for different cropping patterns in Bangladesh. Presentation: poster, Symposium No. 14, Paper No. 1284, $17^{\text {th }}$ WCSS, August 14-21, 2002, Thailand.

Jackson, M. L. (1973). Soil Chemical Analysis (p. 498). Prentice Hall of India Private Limited, New Delhi.

Jacobsen, J. S., \& Jasper, C. D. (1991). Diagnosis of Nutrient Deficiencies in Alfalfa and Wheat. EB 43, February, 1991. Bozeman, Mont. Montana State University Extension.

Jahan, M. A. H. S., Sarkar, M. A. R., Barma, N. C. D., Mondal, M. N. A., \& Ferdousi, M. N. S. (2015a). Seed yield, nutrient balance and economics of mungbean cultivation as influenced by different nutrients management under AEZ-28. Bangladesh Journal of Agricultural Research, 40(1), 77-93. https://doi.org/ 10.3329/bjar.v40i1.23762

Jahan, M. A. H. S., Sarkar, M. A. R., Barma, N. C. D., Mondal, M. N. A., \& Ferdousi, M. N. S. (2015b). Grain yield, nutrient balance and economics of T. aman rice cultivation as influenced by nutrients management. Bangladesh Journal of Agrilcultural Research, 40(1), 17-34. https://doi.org/10.3329/bjar.v40i1.23752

Kabir, M. J., Golam Hafeez, A. S. M., Haque, M. A., Islam, M. S., \& Nabi, M. N. (2002). Marginal analysis of fertilizer trials of jute based cropping pattern. Bangladesh J. Agric. Res., 27(4), 669-680.

Kalra, P. K. (editor) (1998). Handbook of reference Methods for Plant Analysis. Published by CRC Press, Taylor \& Francis Group. New Yark.

Khurmi, R. S. (1987). A Text Book of Hydraulics (pp. 290-291). Chand and company (Private) Limited. Ram Nagar, New Delhi. 
Kirk, G. J. D., Yu, T. R., \& Choudhury, F. A. (1990). Phosphorus chemistry in relation to water regime. Phosphorus requirements for sustainable agriculture in Aisa and Oceania (pp. 211-223). Los Banos, Philippines: IRRI.

Klute, A. (1965). Laboratory measurement of hydraulic conductivity of saturated soil. In C. A. Black (Ed.), Methods of Soil Analysis, Part I (pp. 210-220). American Society of Agronomy, Madison, Wisconsin, USA.

Kumar, K., \& Goh, K. M. (2000). Biological nitrogen fixation, accumulation of soil nitrogen and nitrogen balance for white clover (Trifolium repens L.) and field pea (Pisum sativum L.) grown for seed. Field crops Res, 68, 49-59. https://doi.org/10.1016/S0378-4290(00)00109-X

Kumar, S., \& Singh, M. (Eds.). (2009). 25 Years of Pulses Research at IIPR, 1984-2009 (pp. 68-69). Indian Institute of Pulses Research, Kanpur, India.

Ladha, J. K., Dawe, D., Pathak, H., Padre, A. T., Yadav, R. L., Singh, B., ... Hobbs, P. R. (2003). How extensive are yield declines in long-term rice-wheat experiments in Asia? Field Crops Res, 81, 159-180. https://doi.org/10.1016/S0378-4290(02)00219-8

Lal, B., \& Tiwari, D. D. (2014). Nutrient management in mung bean (Vigna radiata L.) through sulphur and biofertilizers. Legume Res., 37(2), 180-187. https://doi.org/10.5958/j.0976-0571.37.2.027

Lehmann, J., \& Schroth, G. (2003). Nutrient leaching. In G. Schroth \& F. L. Sinclair (Eds.), Trees, Crops and Soil Fertility. CAB International.

Lindsay, W., \& Norvell, W. A. (1978). Development of a DTPA soil test for Zn, Fe, Mn and Cu. Soil Sci. Soc. Am. J., 42, 421-428. https://doi.org/10.2136/sssaj1978.03615995004200030009x

Mondal, R. I., Begum, F., Aziz, A., \& Sharif, S. H. (2015). Crop sequences for increasing cropping intensity and productivity. SAARC J. Agri., 13(1), 135-147. https://doi.org/10.3329/sja.v13i1.24187

Nawab, K., Amanullah Shah, P., Rab, A., Arif, M., Azim Khan, M., Mateen, A., \& Munsif, F. (2011). Impact of integrated nutrient management on growth and grain yield of wheat under irrigated cropping system. Pakistan Journal of Botany, 43(4), 1943-1947.

Nelson, D. W., \& Sommers, L .E. (1982). Total carbon, organic carbon and organic matter. In A. L. Page, R. H. Miller, \& D. R. Keeney (Eds.), Methods of Soil Analysis (Part 2, 2nd ed., pp. 539-580). Am. Soc. of Agron., Madison, USA.

Olsen, S., \& Sommer, L. E. (1982). Phosphorus. In A. L. Page, R. H. Miller, \& D. R. Keeney (Eds.), Methods of Soil Analysis (Part 2, 2nd ed., pp. 403-427). Am. Soc. of Agron., Madison, USA.

Page, A. L., Miller, R. H., \& Keeney, D. R. (Eds.). (1982). Agronomy Series 9 ASA, SSSA. Methods of Soil Analysis (Part 2, 2nd ed., pp. 403-427). Am. Soc. of Agron., Madison, USA.

Panaullah, G. M., Timsina, J., Saleque, M. A., Ishaque, M., Pathan, A. B. M. B. U., Connor, D. J., ... Meisner, C. A. (2006). Nutrient uptake and apparent balances for rice-wheat sequences. III. Potassium. Journal of Plant Nutrition, 29, 173-187. https://doi.org/10.1080/01904160500416554

Paramasivan, M., Malarvizhi, P., \& Thiyageswari, S. (2012). Balanced use of inorganic fertilizers on maize (Zea mays) yield, nutrient uptake and soil fertility in alfisols. Karnataka J. Agric. Sci., 25(4), 423-426.

Paul, F., Brentrup, F., Bruu Isema, T., Garcia, F., Norton, R., \& Zingore, S. (2014). Nutrient/fertilizer use efficiency: Measurement, current situation and trends. IFA, IWMI, IPNI and IPI.

Phong, L. T., Stoorvogel, J. J., Van Mensvoort, M. E. H., \& Udo, H. M. J. (2011). Modeling the soil nutrient balance of integrated agriculture-aquaculture systems in the Mekong Delta, Vietnam. Nutrient Cycling in Agroecosystems, 90, 33-49. https://doi.org/10.1007/s10705-010-9410-4

Piper, C. S. (1966). Soil and Plant Analysis. Adelaide University Press, Australia.

Plant Analysis Handbook. (2017). Agricultural \& Environmental Services Laboratories, College of Agricultural \& Environmental Sciences. University of Georgia.

Prasad, M., \& Prasad, R. (1983). Removal of nitrogen, phosphorus and potassium by rice-wheat double cropping system as affected by duration of rice variety, methods of planting rice and levels and sources of nitrogen. Plant Soil, 70, 287-295. https://doi.org/10.1007/BF02374787

Prasad, P. V. V., Satyanarayana, V., Muthy, V. R. K., \& Boote, K. J. (2002). Maximizing yields in rice-groundnut cropping sequence through integrated nutrient management. Fields Crops Research, 75(2002), 9-21. https://doi.org/10.1016/S0378-4290(01)00214-3 
Prasad, R., Sharma, S. N., \& Singh, S. (1999). Summer mung for sustaining rice-wheat cropping system (pp. 1-11). Bulletin of National Professor's Unit, Division of Agronomy, Indian Agricultural Research Institute, New Delhi, India.

Quayyum, M. A., Timsina, J., Haq, F., Torofder, G. S., \& Connor, D. J. (2001). Effect of fertilizer and pre-monsoon crops on productivity of Rice (Oryza sativa)-Wheat (Triticum aestivum) cropping systems. Indian Journal of Agronomy, 46(4), 584-591.

Quayyum, M. A., Timsina, J., Jahan, M. A. H. S., Ara, R., \& Connor, D. J. (2002). Grain Yield and System Productivity for Rice-Wheat-Mungbean and Rice-Wheat-Maize Sequences in Northern Bangladesh. Thai $J$ Agric Sci, 35(1), 51-62.

Quddus, M. A., Rashid, M. H., Hossain, M. A., Naser, H. M., \& Abedin Mian, M. J. (2012). Integrated nutrient management for sustaining soil fertility through chickpea-mungbean-T. aman cropping pattern at madaripur region. Bangladesh J. Agril. Res., 37(2), 251-262. https://doi.org/10.3329/bjar.v37i2.11226

Quddus, M. A., Abedin Mian, M. J., Naser, H. M., Hossain, M. A., \& Sattar, M. A. (2017). System Yields, Nutrient Uptake and Balance of Mustard-Mungbean-T. Aman Rice Cropping Systems in Terrace Soils of Bangladesh. Journal of Energy and Natural Resources, 6(2), 14-23. https://doi.org/10.11648/j.jenr.20170 602.11

Rahman, M. H., Islam, M. R., Jahiruddin, M., \& Haque, M. Q. (2011). Economics of fertilizer use in the Maize-Mungbean/Dhaincha-T. aman rice cropping pattern. J. Bangladesh Agril. Univ., 9(1), 37-42.

Rahman, M. S., Khan, F. R., Ali, M. R., Biswas, M., \& Haque, M. M. (2004). Effect of organic and inorganic fertilizers on Mustard-Boro-T. Aman cropping pattern irrigated medium high land. Bangladesh Journal of Progressive Science \& Technology, 2(2), 105-108.

Rashid, M. A. (2005). Ground Water Management for Rice Irrigation in Barind Area of Bangladesh (pp. 210-211). Ph.D. Thesis, Department of Irrigation and Management, BAU, Mymensingh.

Regmi, A. P., Ladha, J. K., Pasquin, E., Pathak, H., Hobbs, P. R., Shrestha, L.L., ... Duveiller, E. (2002). The role of of potassium in sustaining yields in a long term rice, wheat experiment in the Indo-Gangetic Plains of Nepal. Biology and fertility of Soils, 36, 240-247. https://doi.org/10.1007/s00374-002-0525-X

Reuter, D. J., Robinson, J. B., \& Dutkiewicz, C. (Eds.). (1997). Plant analysis: An interpretation manual (2nd ed.). Melbourne, Australia: CSIRO Publishing.

Rundala, S. R., Kumawat, B. L., Choudhary, G. L., Prajapat, K., \& Sit, K. (2013). Performance of Indian mustard (Brassica juncea) under integrated nutrient management. Crop Res., 46(1, 2, \& 3), 115-118, India.

Saleque, M. A., Timsina, J., Panaullah, G. M., Ishaque, M., Pathan, A. B. M. B. U., Connor, D. J., ... Meisner, C. A. (2006). Nutrient Uptake and Apparent Balances for Rice-Wheat Sequences. II. Phosphorus. Journal of Plant Nutrition, 28, 157-172. https://doi.org/10.1080/01904160500416547

Shahiduzzaman, M., \& Rahman, M. A. (2008). Nutrient management for sustaining soil fertility and yield of Mustard-Rice-Rice cropping pattern. Annual Research Report, 2007-2008 (pp. 81-85). Soil Science Division, Bangladesh Agricultural Research Institute, Gazipur.

Sharif, M. (2009). Dynamics of potassium in paddy soils. Ph.D. Thesis, Department of Soil Science, Bangladesh Agricultural University, Mymensingh.

Sheikh, M. H. R., Khan, M. S., Hannan, A., Huda, A., \& Rahman, M. T. (2009). Sustainable crop production retaining soil fertility and environment through Mustard-Mungbean-T. Aman cropping pattern. Journal of Soil Nature, 3(2), 10-14.

Shrestha, R. K., \& Ladha, J. K. (2001). Nutrient balances in a rice-vegetable system: a case study of an intensive cropping system in Ilocos Norte, the Philippines. International Workshop on Nutrient Balances for Sustainable Agricultural Production and Natural Resource Management in Southeast Asia, Bangkok, Thailand.

Singh, A. K., Singh, P. K., Manoj, K., Bordoloi, L. J., \& Jha, A. K. (2014). Nutrient Management for Improving Mungbean [Vigna radiate (L.) Wilczek] Productivity in Acidic Soil of Northeast India. Indian Journal of Hill Farming, 27(1), 37-41.

Smaling, E. M. A., Stoorvogel, J. J., \& Windmeijer, P. N. (1993). Calculating soil nutrient balances in Africa at different scales. 2. District Scale. Fert. Res., 35, 237-250. https://doi.org/10.1007/BF00750642 
Talele, P. E., Zende, G. K., Patil, Y. M., Sonar, K. R., \& Tamboli, B. D. (1993). Effect of added K and incubation time on transformation of available $\mathrm{K}$ and non exchangeable $\mathrm{K}$ in different soils of Moharashtra. Journal of Indian Society of Soil Science, 41, 238-42.

Tanada, T. (1983). Localization of boron in membranes. Journal of Plant Nutrition, 6, 743-749. https://doi.org/ $10.1080 / 01904168309363142$

Tarafder, M. A., Haque, M. Q., Rahman, M. M., \& Khan, M. R. (2008). Direct and residual effect of sulphur and zinc on potato-boro-T. aman rice cropping pattern. Progress Agric, 19(1), 33-38. https://doi.org/10.3329/ pa.v19i1.16987

Timsina, J., Panaullah, G. M., Saleque, M., Ishaque, M., Pathan, A. B. M. B. U., Quayyum, M. A., ... Meisner, C. A. (2006). Nutrient Uptake and Apparent Balances for Rice-Wheat Sequences. I. Nitrogen. Journal of Plant Nutrition, 29, 137-155. https://doi.org/10.1080/01904160500416539

Tirol-Padre, A., Ladha, J. K., Regmi, A. P., Bhandari, A. L., \& Inubushi, K. (2007). Organic amendment affect soil parameters in two long-term rice-wheat experiments. Soil Sci Soc Am J, 71, 442-52. https://doi.org/ 10.2136/sssaj2006.0141

Vaidyanathan, A. (1987). Agricultural Development in Eastern India. Economic and Political Weekly, 22(52).

Verma, C. K., Prasad, K., \& Yadav, D. D. (2012). Studies on response of sulphur, zinc and boron levels on yield, economics and nutrients uptake of mustard [Brassica juncea (L.) Czern \& Coss.]. Crop Res., 44(1 \& 2), 75-78.

Vinay, B., Patil, S. K., Sarawgi, S. K., \& Chowdhury, V. K. (2007). Effect of potassium application on yield and potassium content and uptake in Vertisol of Chhattisgarh under rice-wheat cropping sequence. Environmental Ecology, 25, 89-91.

Yamakawa, Y., Saigusa, M., Okada, M., \& Kobayashi, K. (2004). Nutrient uptake by rice and soil solution composition under atmospheric $\mathrm{CO}_{2}$ enrichment. Plant and Soil, 259, 367-372. https://doi.org/10.1023/ B:PLSO.0000020988.18365.b5

Yoshida, S. (1981). Fundamentals of rice crop science. Los Banos, Philippines:IRRI.

Yu, Y. L., Xue, L. H., \& Yang, L. Z. (2014). Winter legumes in rice crop rotations reduces nitrogen loss, and improves rice yield and soil nitrogen supply. Agron. Sustain Dev., 34, 633-40. https://doi.org/10.1007/ s13593-013-0173-6

Yulin, L., Shengxian, Z., Yanhong, L., Zengping, Y., Jun, N., \& Jian, X. (2010). Long-term effect of fertilizer application on rice yield, potassium uptake in plants, and potassium balance in double rice cropping system. Front. Agric. China, 4(4), 406-415. https://doi.org/10.1007/s11703-010-1043-5

Zhang, H., Xu, M., Shi, X., Li, Z., Huang, Q., \& Wang, X. (2010). Rice yield, potassium uptake and apparent balance under long-term fertilization in rice-based cropping systems in southern China. Nutr. Cycl Agro. Ecosyst., 88, 341-349. https://doi.org/10.1007/s10705-010-9359-3

\section{Copyrights}

Copyright for this article is retained by the author(s), with first publication rights granted to the journal.

This is an open-access article distributed under the terms and conditions of the Creative Commons Attribution license (http://creativecommons.org/licenses/by/4.0/). 